\title{
Comparative Influence of Dehulling on the Composition, Antioxidative and Functional Properties of Sorrel (Hibiscus sabdariffa L.) Seed
}

\author{
Helen N. Ayo-Omogie*, Abimbola A. Osanbikan \\ Department of Food Science and Technology, Federal University of Technology, Akure, Nigeria \\ Email: ^hnayo-omogie@futa.edu.ng, *helenatum2002@yahoo.com
}

How to cite this paper: Ayo-Omogie, H.N. and Osanbikan, A.A. (2019) Comparative Influence of Dehulling on the Composition, Antioxidative and Functional Properties of Sorrel (Hibiscus sabdariffa L.) Seed. Food and Nutrition Sciences, 10, 148-173. https://doi.org/10.4236/fns.2019.102012

Received: December 28, 2018

Accepted: January 30, 2019

Published: February 2, 2019

Copyright $\odot 2019$ by author(s) and Scientific Research Publishing Inc. This work is licensed under the Creative Commons Attribution International License (CC BY 4.0).

http://creativecommons.org/licenses/by/4.0/ (c) (i) Open Access

\begin{abstract}
Although animal proteins provide indispensable amino acids that the body requires for normal growth, maintenance and function, their expensiveness makes them unaffordable especially for most families in the developing countries. This has given impetus to extensive research into under-utilized protein-rich oilseeds such as sorrel as possible alternate sources of good quality protein for tackling the challenge of protein-energy malnutrition which is fast becoming a global challenge. Sorrel seed may hold great potentials as a source of good quality protein, however the presence of hard seed coat, bitter after-taste and associated antinutritional factors have limited its use as protein supplement for humans and food ingredient. This study therefore compared the effect of dehulling sorrel seed to boiling, germination and roasting. This was with the aim of enhancing its utilization as protein source for human nutrition and functional ingredient in food product development. Flours obtained were analyzed for their proximate, mineral, antinutrient, amino and fatty acids composition; in vitro starch and protein digestibility, and functional and antioxidative properties. Protein content (ranged from 24.93\% - 32.91\%) significantly increased due to processing; dehulling alone accounted for a percentage increase of $32.01 \%$. Similarly, dehulling increased all essential amino acids (except isoleucine and valine) at percentage which ranged from $3.63 \%-61.17 \%$ whereas other processing methods caused significant reductions. Lysine, leucine, valine, arginine and phenylalanine were the most abundant essential amino acids, while methionine and cystine were the first and second limiting amino acids. Palmitic, linoleic, oleic and stearic acids were the most abundant fatty acids. Mineral composition was $\mathrm{K}>\mathrm{Ca}>\mathrm{Mg}>\mathrm{Na}>$ $\mathrm{Fe}>\mathrm{Zn}>\mathrm{Mn}$. Dehulled seed flour had highest in vitro protein digestibility
\end{abstract}


(75.87\%). Improved amino acid composition, antioxidative and functional properties of sorrel seed flour due to dehulling may indicate the potential of this flour to serve as a protein supplement and functional ingredient for food product development.

\section{Keywords}

Dehulling, Amino Acid Composition, Functional Properties, In Vitro Protein

Digestibility, Human Nutrition, Processing, Protein-Energy Malnutrition, Under-Utilized Sorrel Seed

\section{Introduction}

Malnutrition, currently one of the most devastating challenges being faced globally, is the most important risk factor for illness and death worldwide; with hundreds of millions of pregnant women and young children particularly affected [1] [2]. Particularly in developing countries (Asia and Africa), protein-energy malnutrition (PEM) is the major health challenge and leading nutrition problem most prevalent. This situation is further worsened by the increasing level of poverty which has been reported to be the major cause of malnutrition [3]. Hence, diets of most households in these regions are frequently deficient in macronutrients (protein, carbohydrates and fat, leading to proteinenergy malnutrition), micronutrients (electrolytes, minerals and vitamins, leading to specific micronutrient deficiencies) or both [2] [4]. Although animal proteins provide indispensable (essential) amino acids that the body requires for synthesis of tissue and organ proteins and other nitrogen-containing compounds necessary for normal growth, maintenance and function [5]; their relative expensiveness makes them largely unaffordable for most families especially in the developing countries. Thus, most staple foods in these regions are largely composed of starch.

The major nutrition challenge for governments of both developing and industrialized societies is being able to provide their populations with adequate amounts of food proteins to meet physiological and nutritional requirements [6]. Direct human consumption of oilseeds has the potential to improve the protein content and quality of diets of over half of the world's population. Hence, Müller and Krawinkel [2] have suggested the use of locally available protein- and micronutrient-rich leguminous plants as an effective and sustainable intervention needed to tackle the problems of protein-energy malnutrition and micronutrient deficiency in developing countries. This is because in contrast to low protein content of cereal grains (6\% - 14\%), oilseeds and legumes have high protein content $(20 \%-25 \%)$, are adapted to grow under a wide variety of climatic conditions, are relatively cheap and since they are already a part of the diet in many parts of the world, efforts to increase their consumption is greatly simplified [7]. Usually, legumes (rich in lysine but poor in methionine and cystine) 
are complemented with starchy foods such as cereals (deficient in lysine but rich in methionine and cystine), roots and tubers like rice, millet, maize, yam, cassava, potatoes and sorghum to provide an alternative source of dietary protein of vegetable origin [8]. Extensive research on a number of these legumes (including soybean, cottonseed, sunflower and peanut) has resulted in their wide acceptance and utilization in human nutrition at both domestic and industrial levels. This has made them almost as expensive as animal protein and in some cases not readily available since quantities produced are never enough to meet the high demands for production of a wide range of products, isolates, concentrates, oil and flour [9]. This has necessitated exploiting new protein sources from other under-utilized protein-rich oilseeds; as such attention has been recently shifted to under-utilized protein-rich legumes and oilseeds that can be used as alternative protein sources in food ingredients and functional foods formulation [2] [10].

Sorrel (Hibiscus sabdariffa L.) seed is one of the under-utilized protein-rich seeds with promising nutritional potentials and is currently attracting research interest as a source of good quality protein [11] [12]. A member of the Malvaceae family, sorrel plant also known as Roselle is one of the over 300 species of hibiscus around the world and one of the most common flower plants grown worldwide. This is because it is relatively easy to grow, can be grown as part of multi-cropping systems and is usually grown as a home garden crop due to its ease to maintain [13] [14]. In comparison with other seeds such as black seed, sunflower seed, melon seed, chickpea, pigeon peas, cowpea, soybean and groundnut, sorrel seed contains higher protein content $(32.28 \%-34 \%)$ and its essential amino acid profile is comparable to soybeans. It also contains high amounts of cellulose, dietary fibre, minerals such as phosphorus, calcium and magnesium, vitamins $\mathrm{C}$ and $\mathrm{E}$; a good source of cholesterol-free vegetable oil rich in unsaturated and essential fatty acids like linoleic acid. The high dietary fibre $(39 \%-42 \%)$ of the seed contributes to its strength when compared with other common sources such as wheat, rice bran, oat and fibre [13]-[18]. Hence, this highly-nutritious seed possesses features that can make it serve as a potential good quality protein source that can supplement the often high starch staples frequently consumed in developing countries.

Despite these, sorrel seed is still grossly under-utilized both as protein supplement for humans or functional ingredient in food product development; as such large quantities are usually discarded as by-products after removal of the calyces in most producing areas. Its major use is as animal feed, although the fermented extract of the seed has been reportedly used in some countries as condiment for soup preparation while the residue is mostly thrown away or used as animal feed [19]. This process avoids the ingestion of the whole seed kernel, thus depriving humans of essential nutrients that could be derived from actual consumption of the seed kernel. This is due to the bitter after-taste associated with its hard seed coat which is also high in antinutritional factors and food toxicants [14] [20]. This has also limited the use of sorrel seed in food product de- 
velopment and till date no study has reported any final product application for sorrel seed or any use as protein supplement for human nutrition. According to Carter et al. [21], processing technology is one of the factors that limit the maximum utilization of oilseeds; appropriate processing techniques are very vital to harnessing the abundant nutrients in these plant proteins for human nutrition while inefficient processing techniques limit maximum utilization of legumes and oilseeds. Hence, processes such as drying, sundrying, boiling, roasting, fermentation and germination which have been extensively reported to reduce antinutrient contents and improve nutritional value and digestibility of sorrel seed [14] [15] [16] [17] [18] have not transformed to wide acceptance and maximum utilization of the seed for human nutrition. Hence, to explore its potential as a protein source and food ingredient and make its nutrients more easily accessible, the seed coat has to be removed (dehulled). Apart from seed coat/hull removal, dehulling also enhances texture, appearance, cooking time, digestibility of protein, palatability, nutritive value and colour of food due to removal of antinutritional and toxic factors which abound in the seed coat [22].

Presently, information is lacking on the effect of dehulling on sorrel seed composition and this is vital to effectively maximize it as a protein supplement and functional ingredient for formulation of new food products. Information is also lacking on the functional properties of both raw and processed sorrel seed flours, while reports on the antioxidative potential and bioactive composition of the processed and raw seed flours (which provide information on the healthpromoting potential of the seed) are scarce. Information on functional properties is relevant to determine the level of utilization of flours in ingredient formulation and food product development [23]. This present study has therefore compared the effect of dehulling to two heat processing methods (boiling and roasting) and germination on the nutrient and antinutrient composition, amino and fatty acid profiles, in-vitro protein and starch digestibility, antioxidative and functional properties of sorrel seed. It is expected that results of this study will provide baseline information that will stimulate extensive research into optimization and mechanization of the dehulling process of sorrel seed. This will consequently take out the drudgery associated with the manual dehulling process and encourage production and utilization of the dehulled seed flour. Also, this study has proposed utilization possibilities of dehulled sorrel seed flour as a potential functional ingredient in food product development and protein supplement.

\section{Materials and Methods}

\subsection{Sample Acquisition and Pretreatment}

Red sorrel seeds $(10 \mathrm{~kg})$ were obtained from a local farm in Sokoto State, Nigeria and transported to the Federal University of Technology, Akure, Ondo State, Nigeria where this study was carried out from May to December, 2017. All reagents and chemicals used were of analytical grade. 


\subsection{Processing of Sorrel Seed and Production of Processed Flours}

The seeds were sorted, washed severally with clean tap water to remove dirt and foreign materials, drained and divided into 5 equal portions of $2 \mathrm{~kg}$ each for preparation of flours.

\subsubsection{Raw Oven-Dried Sorrel Seed Flour}

Raw oven-dried sorrel seed flour which served as the control was prepared by oven drying the washed seeds at $60^{\circ} \mathrm{C}$ until a constant weight was obtained [24].

\subsubsection{Dehulled Sorrel Seed Flour}

This was prepared by boiling the washed seeds in an aluminium pot at $100^{\circ} \mathrm{C}$ until the seed coat was soft; drained, cooled and dehulled manually by rubbing between the palms to extract the kernels from the hulls. Clean tap water was thereafter poured in and the hulls separated from the kernels by repeated sieving.

\subsubsection{Boiled Sorrel Seed Flour}

Washed seeds were boiled with distilled water at $100^{\circ} \mathrm{C}$ for $1 \mathrm{~h}$ in an aluminium pot and drained [12].

\subsubsection{Roasted Sorrel Seed Flour}

The method of Duwa et al. [25] was adopted for preparation of roasted sorrel seed flour. Washed seeds were roasted for $40 \mathrm{~min}$ at $100^{\circ} \mathrm{C}$ in a frying pan placed on an electric cooker and allowed to cool to ambient temperature $\left(25^{\circ} \mathrm{C} \pm 2^{\circ} \mathrm{C}\right)$.

\subsubsection{Germinated Sorrel Seed Flour}

Washed seeds were steeped in 1 litre of distilled water at room temperature for $24 \mathrm{~h}$; thereafter drained, spread on a clean moistened jute bag and allowed to germinate at room temperature $\left(25^{\circ} \mathrm{C} \pm 2^{\circ} \mathrm{C}\right)$ to a mean sprout height of $0.5 \mathrm{~cm}$ [12].

All processed seeds, apart from the roasted seeds, were oven dried at $60^{\circ} \mathrm{C}$ until a constant weight was obtained, milled using a Waring Commercial Blender (Model 24CB10, USA), sieved using a mesh aperture of $0.4 \mathrm{~mm}$, packaged in different airtight containers, labeled appropriately and stored at $4^{\circ} \mathrm{C}$ for further analyses.

\subsection{Determination of Chemical and Amino and Fatty Acid Compositions of Sorrel Seed Flours}

Proximate composition of the seed flours was determined using the standard methods of Association of Official Analytical Chemists [26]. Crude protein content was determined by the micro Kjeldahl nitrogen method and a conversion factor of 6.25 was used to convert the nitrogen content to protein. Carbohydrate content was calculated by difference $(100-[$ moisture + total ash + crude fat + crude fiber + protein]).

Mineral element composition was determined using the methods described by 
Isaac and Johnson [27] and Jones and Case [28]. Briefly, triplicate samples (1 g each) were ashed using a muffle furnace at $500^{\circ} \mathrm{C}$ in clean ceramic crucibles for the first $2 \mathrm{~h}$ and thereafter held for another $2 \mathrm{~h}$ to cool to room temperature. The ash were digested using distilled water, $400 \mathrm{ml}$ conc. $\mathrm{HCl}$ and $133 \mathrm{ml} 70 \%$ Nitric acid and diluted with distilled water to 2 litre mark in a volumetric flask to produce the Aqua Regia solution. The mixture was vortexed and thereafter centrifuged at $3000 \mathrm{rpm}$ for $10 \mathrm{~min}$. The clear supernatant was decanted into vials for mineral determination using the Unicam 919 atomic absorption spectrophotometer (Unicam Ltd, Cambridge, UK) for $\mathrm{Ca}, \mathrm{Mg}, \mathrm{Mn}, \mathrm{Zn}$ and $\mathrm{Fe}$. $\mathrm{K}$ and $\mathrm{Na}$ were determined using flame photometer (Corning EEL), and phosphorus by Phospho-vanadomolybdate method [26].

The amino acid profile of the seed flours was determined using the Ion Exchange chromatography (IEC). Briefly, triplicate samples were defatted using chloroform/methanol mixture of 2:1, hydrolyzed, evaporated in a rotary evaporator and injected into the Technicon sequential multisampling Amino Acid Analyzer (TSM). Fatty acid profile was determined by the method of Oh [29]. Fatty acids were extracted using a $\mathrm{CHCl}_{3} \cdot \mathrm{MeOH}(2: 1 \mathrm{v} / \mathrm{v})$ solution. The samples were centrifuged at $3000 \mathrm{rpm}$, supernatant collected were mixed with $0.9 \% \mathrm{NaCl}$ solution and centrifuged again at $3000 \mathrm{rpm}$. The $\mathrm{CHCl}_{3}$ phase was evaporated under nitrogen gas and treated with $14 \%$ boron trifluoride methanol solution $\left(\mathrm{BF}_{3}-\mathrm{MeOH}\right)$ for $10 \mathrm{~min}$ at $100^{\circ} \mathrm{C}$. After cooling to room temperature, $1 \mathrm{ml}$ water and $2 \mathrm{ml}$ pentane were added. The pentane phase was evaporated under nitrogen gas and dissolved in $\mathrm{n}$-hexane. Fatty acid composition was analyzed using a gas chromatography (GC) (Acme 6000, Young-Lin Co.), which was equipped with a flame ionization detector (FID) and SPMTM-fused silica capillary column $(130 \mathrm{~mm} \times 0.25 \mathrm{~mm}, 0.25 \mu \mathrm{m}$, Supeico Co. USA). Nitrogen gas was used as carrier. Individual fatty acid methyl esters (FAME) were quantified as a percentage of total FAME analyzed. Free fatty acid was determined by Akintayo and Bayer [30] method.

Total carotenoid content of samples was determined by methods described by Rodríguez-Amaya and Kimura [31] with slight modifications. Briefly, $2.5 \mathrm{~g}$ of each sample was weighed into a conical flask. $30 \mathrm{ml}$ hexane, $20 \mathrm{ml}$ ethanol and 2 $\mathrm{ml} 2 \% \mathrm{NaCl}$ solution were added and mixed thoroughly. The solution was transferred into a separating funnel and allowed to stand for $10 \mathrm{~min}$ to aid extraction of carotenoid. The lower content of the solution was run off and the upper layer was collected and absorbance was measured at $454 \mathrm{~nm}$. Sample preparation and readings were done under less intense light in the laboratory because of the sensitivity of carotenoid to light. Total carotenoid content (mg/100g) was calculated and expressed on dry weight basis using the following equation:

$$
\text { Total carotenoid content }(\mu \mathrm{g} / \mathrm{g})=\frac{\mathrm{A} \times \operatorname{Volume}(\mathrm{mL}) \times 10^{4}}{\mathrm{~A}_{1 \mathrm{~cm}}^{1 \%} \times \text { sample weight }}
$$

where $\mathrm{A}=$ absorbance; volume $=$ total volume of extract $(25 \mathrm{~mL}) ; \mathrm{A}_{1 \mathrm{~cm}}^{1 \%}=\mathrm{ab}$ - 
sorption coefficient of $\beta$-carotene in PE (2592), PE-Petroleum ether.

\subsection{Determination of In-Vitro Starch and Protein Digestibility}

In vitro protein digestibility (IVPD) of the seed flours was determined using the multienzyme procedure of Hsu et al. [32]. Enzymes used were porcine pancreatic trypsin (ZF.93615.0025), bovine pancreatic chymotrypsin (ZF.27270) and porcine intestinal peptidases (Z.F.77163.0500, Zefa Lab service, GMBH Germany). The activity of the enzymes was initially determined before use by using them to digest casein. One hundred milligrams $(100 \mathrm{mg})$ of each of the seed flour was dispersed in $1 \mathrm{ml}$. Each sample suspension was adjusted to $\mathrm{pH} 8.0$ and incubated in water bath at $3^{\circ} \mathrm{C}$ with constant stirring. Fresh Multienzyme solution was prepared to contain $1.6 \mathrm{mg}$ trypsin, $3.1 \mathrm{mg}$ chymotrypsin and $1.4 \mathrm{mg}$ peptidase dissolved in $1 \mathrm{ml}$ distilled water. The $\mathrm{pH}$ of enzyme solution was maintained at 8.0. Five millimeter $(5 \mathrm{ml})$ of the multienzyme solution was added to each sample suspension with constant stirring at $37^{\circ} \mathrm{C}$. The $\mathrm{pH}$ of each sample suspension was recorded at $10 \mathrm{~min}$ and $15 \mathrm{~min}$ respectively after adding the enzyme solution. IVPD was calculated using the equation of Hsu et al. [32]. In vitro starch digestibility was determined using pancreatic amylase [33]. Briefly, 50 $\mathrm{mg}$ of each sample was dispersed in $1 \mathrm{ml}$ of $0.2 \mathrm{M}$ phosphate buffer ( $\mathrm{pH}$ 6.9). Twenty milligrams of the enzyme was dissolved in $50 \mathrm{ml}$ of the same buffer and $0.2 \mathrm{ml}$ of both the sample and enzyme were added. The mixture was heated for 5 min in a boiling water bath, cooled thereafter and the absorbance was read at $540 \mathrm{~nm}$ against a blank containing buffer while maltose was used as a standard.

\subsection{Determination of Anti-Oxidant Potentials and Free Radical Scavenging Activity}

\subsubsection{DPPH Free Radical Scavenging Ability}

DPPH free radical-scavenging ability of the samples was measured using spectrometric assay of Butrits and Bucar [34] which measures hydrogen atom or electrons-donating ability from the bleaching of purple-coloured methanolic DPPH solution. Aqueous extract of $100 \mu \mathrm{l}, 200 \mu \mathrm{l}, 300 \mu \mathrm{l}$ and $400 \mu \mathrm{l}$ containing 2 $\mathrm{mg}, 4 \mathrm{mg}, 6 \mathrm{mg}$ and $8 \mathrm{mg}$ of the sample respectively was dispensed into test tubes and made up to $500 \mu \mathrm{l}$ with distilled water followed by addition of $600 \mu \mathrm{l}$ of methanolic DPPH and incubated in the dark at room temperature for $15 \mathrm{~min}$ and absorbance read at $517 \mathrm{~nm}$ using a JENWAY UV-Visible spectrophotometer (JENWAY Inc.). The DPPH radical-scavenging capacity (\%) was calculated as:

$$
\operatorname{DPPH}(\%)=\frac{\mathrm{Abs}_{\text {reference }}-\left(\mathrm{Abs}_{\text {sample }}-\mathrm{Abs}_{\text {negative }}\right) \times 100}{A \mathrm{Ab}_{\text {reference }}}
$$

\subsubsection{Total Phenolic Content}

Total phenolic content (TPC) of the samples was determined as described by Singleton et al. [35] with slight modification using gallic acid as standard. Fifty microliters $(50 \mu \mathrm{l})$ of the aqueous extract containing $0.5 \mathrm{mg}$ of aqueous extract 
was dispensed into a test tube, $50 \mu \mathrm{l}$ of distilled water and $500 \mu \mathrm{l}$ of Folin-Ciocalteu reagent were added and shaken thoroughly. After $3 \mathrm{~min}$ at room temperature, $400 \mu \mathrm{l}$ of $7.5 \%$ sodium carbonate solution was added and the mixture was incubated in the dark at $45^{\circ} \mathrm{C}$ in a water bath for $40 \mathrm{~min}$ and the absorbance read thereafter at $750 \mathrm{~nm}$ in a JENWAY UV-Visible spectrophotometer. Total phenolic content was expressed as gallic acid equivalent per gram of sample (mg of GAE/g sample) through the calibration curve of gallic acid and calculated as follows:

$$
\text { Total Phenolic Content }(\mathrm{mg} / \mathrm{GAE} / \mathrm{g})=\frac{\mathrm{Abs}_{\text {sample }} \times \text { Conc.Standard }(\mathrm{mg} / \mathrm{ml})}{\mathrm{Abs}_{\text {standard }} \times \operatorname{Conc} . \operatorname{Sample}(\mathrm{g} / \mathrm{ml})}
$$

\subsubsection{Flavonoid Content}

Flavonoid content was determined using the aluminum chloride colorimetric assay [36] with slight modifications. Briefly, $500 \mu \mathrm{l}$ of aqueous extract of the samples was diluted with $500 \mu \mathrm{l}$ methanol in a $10 \mathrm{ml}$ flask. To this $500 \mu \mathrm{l}, 10 \%$ $\mathrm{AlCl}_{3}, 50 \mu \mathrm{l}$ of $1 \mathrm{M}$ potassium acetate and water added to a total volume of 2.5 $\mathrm{mL}$. The solution was incubated at room temperature for $40 \mathrm{~min}$ and absorbance read against blank at $415 \mathrm{~nm}$. Total flavonoid content was calculated thus:

$$
\text { Total Flavonoid Content }(\mathrm{mg} / \mathrm{QE} / \mathrm{G} / \mathrm{g})=\frac{\mathrm{Abs}_{\text {sample }} \times \text { Conc.Standard }(\mathrm{mg} / \mathrm{ml})}{\mathrm{Abs}_{\text {standard }} \times \operatorname{Conc} . \operatorname{Sample}(\mathrm{g} / \mathrm{ml})}
$$

\subsubsection{Ferric Reducing Antioxidant Property (FRAP)}

The ferric reducing antioxidant property of the flours was determined using the method of Pulido et al. [37]. $0.25 \mathrm{ml}$ of sample extract $(2.5 \mathrm{~mL})$ was mixed with equal volumes of $0.2 \mathrm{M}$ phosphate buffer ( $\mathrm{pH}$ 6.6) and $1 \%$ potassium ferricyanide $\left[\mathrm{K}_{3} \mathrm{Fe}(\mathrm{CN})_{6}\right]$ and the resulting solution was incubated for $20 \mathrm{~min}$ at $50^{\circ} \mathrm{C}$. Afterwards, $2.5 \mathrm{~mL}$ of freshly prepared $10 \%$ trichloroacetic acid was added and the mixture centrifuged at $600 \mathrm{rpm}$ for $10 \mathrm{~min}$. The supernatant $(5 \mathrm{~mL})$ was mixed with equal volume of distilled water and $1 \mathrm{~mL}$ of $0.1 \% \mathrm{FeCl}_{3}$ and the absorbance was immediately read at $700 \mathrm{~nm}$ using a UV-visible spectrophotometer. Ascorbic acid was used as standard and the ferric reducing power was determined as ascorbic acid equivalent per milliliter of the sample extract.

\subsection{Determination of Some Functional Properties}

Water and oil absorption capacities (WAC and OAC) were determined according to the methods of Rodriguez-Ambriz et al. [38] as described by Omowaye-Taiwo et al. [39]. Each sample (1 g) was weighed into a $15 \mathrm{ml}$ already weighed centrifuge tube and $10 \mathrm{ml}$ of distilled water (for WAC) or $10 \mathrm{ml}$ of soybean oil (with density $0.92 \mathrm{~g} / \mathrm{ml}$ ) (for OAC) was added stepwise with continuous stirring at room temperature for $10 \mathrm{~min}$. Thereafter, the tubes were centrifuged at $2500 \times \mathrm{g}$ for $20 \mathrm{~min}$ and volume of the supernatant measured. The WAC or OAC was calculated as the difference between the initial volume of water or oil used and the final volume of the decanted supernatant and calculated in percen- 
tages (with consideration of the density of the oil). Swelling index was determined by Ukpabi and Ndimele [40] method. A sample size of $25 \mathrm{~g}$ was added to water in a measuring cylinder and left to swell for $4 \mathrm{~h}$ at room temperature. The procedure was replicated thrice and the swelling index was calculated as follows:

$$
\text { Swelling Index }(v / v)=\frac{\text { Final Volume }}{\text { Initial Volume }}
$$

Foaming capacity (FC) and foaming stability (FS) were carried out as described by Sze-Tao and Sathe [41]. The sample $(0.5 \mathrm{~g})$ was dispersed in $50 \mathrm{ml}$ of distilled water in a $100 \mathrm{ml}$ graduated cylinder and the solutions homogenized at a speed of $1600 \times \mathrm{g}$ for $5 \mathrm{~min}$. The volume was recorded before and after whipping. FC was expressed as the volume (\%) increase due to whipping. This was then stored for $1 \mathrm{hr}$ and the foam-volume changes in the graduated cylinder were recorded as FS. Both were calculated in percentages as shown below:

Foaming capacity

$$
\begin{gathered}
=\frac{\text { Volume after homogenization }- \text { Volume before homogenization }}{\text { Volume before homogenization }} \times 100 \\
\begin{array}{c}
\text { Foaming stability } \\
=\frac{\text { Volume of foam after set time }}{\text { Initial volume of foam }} \times 100
\end{array}
\end{gathered}
$$

Emulsion capacity (EC) was determined according to the method of Chavan et al. [10]. One gram of the sample in $25 \mathrm{ml}$ distilled water was homogenized at a speed of $5000 \times \mathrm{g}$ for $1 \mathrm{~min}$ at $27^{\circ} \mathrm{C}$. The protein solution was then mixed with 25 $\mathrm{ml}$ of soybean oil followed by homogenization at $10,000 \times \mathrm{g}$ for $1 \mathrm{~min}$. The emulsion volume was then used in calculating the $\mathrm{EC}$ as shown below:

$$
\text { Emulsion capacity }=\frac{\text { Height of emulsified layer }}{\text { Height of the contents of the tube }} \times 100
$$

The effect of $\mathrm{pH}$ on protein solubility of the seed flours was determined by the method of Palić et al. [42].

\subsection{Determination of Antinutrient Composition}

Phytate was determined according to the method of Wheeler and Ferrel [43] and tannin as described by Makkar [44]. Oxalate was determined according to the method of Day and Underwood [45], while saponin content of the samples was determined using AOAC [46] methods.

\subsection{Statistical Analysis}

All determinations were carried out in triplicate on three independent batches of samples. Data obtained were subjected to analysis of variance (ANOVA) expressed as mean \pm standard deviation using SPSS 16.0 for windows computer software package. The difference in means was compared using Duncan's new Multiple Range test and significant level was established at $\mathrm{P}<0.05$. 


\section{Results and Discussion}

\subsection{Proximate and Mineral Element Compositions and in Vitro Digestibility of Raw and Processed Sorrel Seed Flours}

Crude protein content of the seed flours showed significant $(\mathrm{p}<0.05)$ increase due to processing from $24.93 \%$ to a range of $27.65 \%-32.91 \%$ (\% DW); accounting for a $10.91 \%$ - 32.01\% increase in which dehulling caused the highest increase and roasting the least (Table 1). Values reported in the present study compare well with previous reports [15] [16] [47]; although Emmy Hainida et al. [47] reported that sun-drying and boiling caused crude protein reduction in sorrel seed. However, the increase here corroborates increase reported by Yagoub et al. [18] and Duwa et al. [25] in processed sorrel seed. This increase may be attributed to heat treatment which destroys heat-sensitive anti-nutritional factors such as protein inhibitors that bind to proteins and inactivate enzymes that speed up nutrient damage, hence improving the availability of nutrients [14]. Furthermore, these higher values as compared to those previously reported for some common seeds and grain legumes, such as sunflower seeds, melon seeds, cowpeas, soybeans and groundnuts [48], may make sorrel seed a potential source of cheap and available protein supplement. Dehulling may have resulted in the highest increase due to synergistic activities of seed coat removal and heat treatment applied to the seed before dehulling since hulls have been reported to

Table 1. Proximate composition (\% dry weight), mineral composition (mg/100g), in vitro protein and starch digestibility of processed sorrel seed flours.

\begin{tabular}{|c|c|c|c|c|c|}
\hline \multirow{2}{*}{ Parameters } & \multicolumn{5}{|c|}{ Samples } \\
\hline & RDSF (Control) & DDSF & BDSF & ROSF & GDSF \\
\hline Moisture & $6.40 \pm 0.07^{\mathrm{b}}$ & $5.94 \pm 0.07^{\mathrm{c}}$ & $6.72 \pm 0.07^{\mathrm{a}}$ & $4.36 \pm 1.00^{\mathrm{e}}$ & $5.67 \pm 0.08^{\mathrm{d}}$ \\
\hline Crude protein & $24.93 \pm 1.00^{\mathrm{d}}$ & $32.91 \pm 0.08^{\mathrm{a}}$ & $29.69 \pm 0.08^{b}$ & $27.89 \pm 0.08^{c}$ & $27.65 \pm 0.08^{c}$ \\
\hline Crude fat & $26.24 \pm 1.00^{\mathrm{b}}$ & $25.60 \pm 1.00^{\mathrm{b}}$ & $28.66 \pm 0.12^{\mathrm{a}}$ & $24.44 \pm 0.12^{c}$ & $22.24 \pm 0.12^{\mathrm{d}}$ \\
\hline Total ash & $4.36 \pm 0.45^{\mathrm{a}}$ & $3.16 \pm 0.05^{\mathrm{b}}$ & $3.38 \pm 0.15^{\mathrm{b}}$ & $3.26 \pm 0.01^{\mathrm{bc}}$ & $3.41 \pm 0.04^{\mathrm{b}}$ \\
\hline carbohydrate & $42.00 \pm 0.06^{\mathrm{b}}$ & $36.29 \pm 1.00^{\mathrm{d}}$ & $33.58 \pm 0.06^{\mathrm{e}}$ & $40.01 \pm 1.00^{c}$ & $42.61 \pm 0.06^{\mathrm{a}}$ \\
\hline Sodium & $0.66 \pm 0.01^{\mathrm{d}}$ & $1.11 \pm 0.30^{\mathrm{a}}$ & $1.10 \pm 0.30^{\mathrm{a}}$ & $0.76 \pm 0.02^{c}$ & $0.88 \pm 0.10^{\mathrm{b}}$ \\
\hline Calcium & $20.86 \pm 0.10^{\mathrm{e}}$ & $23.86 \pm 0.01^{c}$ & $25.75 \pm 0.20^{\mathrm{a}}$ & $24.17 \pm 0.10^{\mathrm{b}}$ & $23.02 \pm 0.04^{\mathrm{d}}$ \\
\hline Magnesium & $20.51 \pm 0.02^{\mathrm{b}}$ & $21.61 \pm 0.01^{\mathrm{a}}$ & $21.54 \pm 0.10^{\mathrm{a}}$ & $20.49 \pm 0.01^{b}$ & $20.51 \pm 0.01^{b}$ \\
\hline Manganese & $0.02 \pm 0.01^{\mathrm{bc}}$ & $0.05 \pm 0.01^{\mathrm{b}}$ & $0.11 \pm 0.09^{\mathrm{a}}$ & $0.10 \pm 0.09^{\mathrm{a}}$ & $0.11 \pm 0.09^{\mathrm{a}}$ \\
\hline Zinc & $0.11 \pm 0.98^{\mathrm{a}}$ & $0.12 \pm 0.98^{\mathrm{a}}$ & $0.12 \pm 0.98^{\mathrm{a}}$ & $0.14 \pm 0.98^{\mathrm{a}}$ & $0.14 \pm 0.98^{\mathrm{a}}$ \\
\hline Iron & $0.17 \pm 0.23^{\mathrm{a}}$ & $0.19 \pm 0.23^{\mathrm{a}}$ & $0.19 \pm 0.23^{\mathrm{a}}$ & $0.12 \pm 0.51^{\mathrm{ab}}$ & $0.04 \pm 0.13^{\mathrm{ab}}$ \\
\hline IVPD (\%) & $78.32 \pm 1.00^{\mathrm{a}}$ & $75.87 \pm 1.00^{\mathrm{b}}$ & $72.36 \pm 1.00^{\mathrm{e}}$ & $73.64 \pm 1.00^{\mathrm{d}}$ & $74.40 \pm 1.00^{\mathrm{cd}}$ \\
\hline IVSD (\%) & $59.69 \pm 1.00^{\mathrm{e}}$ & $61.68 \pm 1.00^{\mathrm{d}}$ & $69.86 \pm 1.00^{\mathrm{a}}$ & $67.18 \pm 1.00^{\mathrm{b}}$ & $63.25 \pm 1.00^{c}$ \\
\hline
\end{tabular}

Means \pm standard deviation for at least 3 determinations; Means with different superscripts on the same row are significantly different at $\mathrm{p}<0.05$; Legends: RDSF (Control)_Raw oven-Dried Sorrel Seed Flour; DDSF-Dehulled Dried Sorrel Seed Flour; BDSF-Boiled Dried Sorrel Seed Flour; ROSF_-Roasted Sorrel Seed Flour; GDSF-Germinated Dried Sorrel Seed Flour; IVPD—in vitro protein digestibility; ISPD—in vitro starch digestibility. 
contain significant amounts of anti-nutritional factors [14] [20]. Dehulling may therefore serve as a better processing method for increasing protein content of sorrel seed and the dehulled seed flour may provide a higher source of nutritional protein supplement. Crude fat (ranging from $22.24 \%$ - 28.66\%) reduced due to germination, dehulling and roasting, while boiling significantly $(\mathrm{p}<0.05)$ increased it. Whereas dehulling decreased crude fibre possibly due to removal of hulls; germination, roasting and boiling increased it. Lower values in the present study $(2.04 \%-4.69 \%)$ as compared to those $(13.10$ - 15.50) previously reported by Duwa et al. [25] may be due to sieving of the flours after milling; although comparable values were reported by Kwari et al. [12]. Based on the high protein and moderate crude fibre contents of the dehulled sorrel seed flour (DDSF), this sample may be useful as a cheap, available protein supplement for enriching protein content of cereal-based complementary foods which serve as major weaning staples in Africa including Nigeria. The total ash and carbohydrate (except germinated sorrel seed flour-GDSF) contents of the processed flours were significantly lower than the raw sorrel seed flour (Table 1).

Results obtained showed that potassium (which ranged from 90.0 - 111.41 $\mathrm{mg} / \mathrm{kg}$ ) was the most abundant mineral in both raw and processed sorrel seed flours; the trend in abundance being $\mathrm{K}>\mathrm{Ca}>\mathrm{Mg}>\mathrm{Na}>\mathrm{Fe}>\mathrm{Zn}>\mathrm{Mn}$ (Table 1 ). The predominance of $\mathrm{K}$ corroborates previous reports that potassium is usually the most abundant mineral element in tropical plants and previous workers have similarly reported predominance of $\mathrm{K}$, followed by $\mathrm{Ca}$ and $\mathrm{Mg}$ in sorrel seed [15] [16] [47]. However, processing caused significant variations in the mineral composition of sorrel seed. All processing methods increased $\mathrm{K}$ with the highest increase recorded in the roasted sorrel seed flour (ROSF) and lowest in DDSF, Ca [highest in boiled seed flour (BDSF) and lowest in GDSF], $\mathrm{Na}, \mathrm{Mg}$ and $\mathrm{Mn}$ (increase not significant in DDSF); while $\mathrm{Zn}$ and Fe were not significantly affected. Although increased mineral contents due to processing may be unusual, Emmy Hainida et al. [47] also reported similar increase in $\mathrm{Na}, \mathrm{Ca}$ and $\mathrm{K}$ due to boiling as compared to sun-drying and freeze-drying. This increase may be due to destruction of anti-nutritional factors (ANFs) which bind to mineral elements and reduce their contents and availability [14]. This is further corroborated by reports of Yagoub et al. [18] that processing improves $\mathrm{HCl}$ extractability of minerals; thus explaining the increase observed in this study. Overall, sample DDSF had the lowest mineral contents and may be linked to the lowest total ash recorded in DDSF. This may indicate that the seed's hulls contain more of the inorganic component of the seed; and thus the dehulled seed flour may require micronutrient fortification when being used for protein enrichment if cereal-based complementary foods.

In vitro protein digestibility (IVPD) of sorrel seed flours ranged from $72.36 \%$ $78.32 \%$, comparing favourably with a range of $79 \%-82 \%$ previously reported for sorrel seed and even higher than defatted soybean flour [15] [17] [18]. These high values indicate that the protein of these flours is highly digestible and as 
such can serve as a nutritional source of amino acid, since digestibility is an important factor for determining the nutritional value of proteins [14]. However, there was a reduction of $3.13 \%-7.61 \%$ due to processing, the highest recorded in the boiled seed flour (BDSF) $(72.36 \%)$ and the lowest in the dehulled seed flour (DDSF) (75.87\%) (Table 1). This indicates that the dehulled sorrel seed flour may serve as the best nutritional source of amino acid as compared to other flours, thus further emphasizing the potential of dehulling as the best processing method for production of sorrel seed flour that will serve as an important source of amino acid for human nutrition. Similar reductions have been previously reported and attributed to unfolding of the seed proteins which increases surface contact of embedded hydrophobic amino acids with water molecules, thus reducing solubility and consequently digestibility. Also, it has been reported that during heat treatment, changes occur in proteins resulting in reduced protein digestibility due to formation of isopeptides and high polymer protein fractions [18]. On the other hand, in vitro starch digestibility (IVSD) (which ranged from 59.69\% - 69.86\%) significantly increased due to processing; the highest increase recorded in BDSF and the lowest in DDSF. Heating improves the digestibility of starch through gelatinization and destruction of antinutrients and this may account for the increase in this study since all the processing methods except germination involved heating, whereas increased starch digestibility during germination of legumes may be attributed to activation of the amylolytic enzymes during germination [49].

\subsection{Amino and Fatty Acid Profiles of Raw and Processed Sorrel Seed Flours}

Table 2 shows the effect of processing on the amino acid composition of sorrel seed. Lysine, leucine, valine, arginine and phenylalanine generally had the highest amounts in the samples as compared to other essential amino acids and compared favourably with the reference; while for the non-essential amino acids, higher values were obtained for aspartic and glutamic acids. This is in line with previous reports that leucine, lysine, arginine, phenylalanine, valine and glutamic acid are abundant amino acids in sorrel seed [11] [16] [47]. On the other hand, methionine was the most limiting essential amino acid in the seed and previous workers had reported similarly [16] [17] [47]. Similar results have been reported in other oil-rich protein seeds [50] [51]. Significant reductions occurred due to other processing methods, however, dehulling significantly ( $\mathrm{p}<$ 0.05 ) increased all essential and non-essential amino acids except isoleucine and valine where percentage reduction were $0.88 \%$ and $47.26 \%$, respectively. Highest increase in the essential amino acids in sample DDSF occurred in leucine, methionine, lysine, cystine, threonine, tyrosine, histidine and phenylalanine with percentage increase of $61.17 \% ; 52.27 \%, 12.35 \%, 27.75 \%, 16.09 \%, 13.7 \%, 20.65 \%$, $11.11 \%$, respectively. Similar reductions in amino acids due to heat treatment, germination and fermentation have been reported in sorrel seeds and other 
Table 2. Essential and non-essential amino acid composition of raw and processed sorrel seed flours, whole egg protein and FAO/WHO recommended pattern of human requirement.

\begin{tabular}{|c|c|c|c|c|c|c|c|c|c|c|}
\hline \multirow{2}{*}{$\begin{array}{c}\text { Amino Acid } \\
(\mathrm{g} / 100 \mathrm{~g} \\
\text { protein })\end{array}$} & \multicolumn{5}{|c|}{ Samples } & \multirow[t]{2}{*}{ Reference $^{\mathrm{a}}$} & \multicolumn{4}{|c|}{ Human requirement ${ }^{\mathrm{b}} \mathrm{FAO} / \mathrm{WHO}(56)$} \\
\hline & RDSF & DDSF & BDSF & ROSF & GDSF & & Infant $^{c, d}$ & $\begin{array}{l}\text { Pre-school } \\
\text { children }^{c, e}\end{array}$ & $\begin{array}{c}\text { School } \\
\text { children }^{c, f}\end{array}$ & Adult ${ }^{c}$ \\
\hline \multicolumn{11}{|c|}{ Essential amino acids } \\
\hline Leucine & $5.28 \pm 0.01^{b}$ & $\begin{array}{c}8.51 \pm 0.02^{\mathrm{a}} \\
\quad(>61.17)\end{array}$ & $5.10 \pm 0.05^{c}$ & $4.90 \pm 0.06^{\mathrm{d}}$ & $4.75 \pm 0.12^{\mathrm{d}}$ & 8.3 & 9.3 & 6.6 & 4.4 & 1.9 \\
\hline Isoleucine & $3.39 \pm 0.11^{b}$ & $\begin{array}{c}3.36 \pm 0.01^{\mathrm{b}} \\
\quad(<0.88)\end{array}$ & $3.85 \pm 0.04^{\mathrm{a}}$ & $3.29 \pm 0.03^{\mathrm{b}}$ & $3.00 \pm 0.01^{c}$ & 5.6 & 4.6 & 2.8 & 1.3 & 4.2 \\
\hline Lysine & $5.91 \pm 1.12^{\mathrm{b}}$ & $\begin{array}{l}6.64 \pm 0.01^{\mathrm{a}} \\
\quad(>12.35)\end{array}$ & $4.95 \pm 0.11^{\mathrm{c}}$ & $4.89 \pm 0.02^{c}$ & $4.62 \pm 0.01^{\mathrm{d}}$ & 6.3 & 6.6 & 5.8 & 4.4 & 1.6 \\
\hline Threonine & $2.64 \pm 0.01^{b}$ & $\begin{array}{c}3.06 \pm 0.03^{\mathrm{a}} \\
(>16.09)\end{array}$ & $2.58 \pm 0.04^{c}$ & $2.44 \pm 0.01^{\mathrm{d}}$ & $2.38 \pm 0.02^{\mathrm{d}}$ & 5.1 & 4.3 & 3.4 & 2.8 & 0.9 \\
\hline Methionine & $0.88 \pm 0.02^{\mathrm{b}}$ & $\begin{array}{l}1.34 \pm 0.0 .1^{\mathrm{a}} \\
\quad(>52.27)\end{array}$ & $0.80 \pm 0.01^{b}$ & $0.69 \pm 0.04^{c}$ & $0.67 \pm 0.10^{c}$ & 3.2 & - & - & - & 2.2 \\
\hline Valine & $4.19 \pm 0.01^{\mathrm{a}}$ & $\begin{array}{c}2.21 \pm 0.02^{\mathrm{e}} \\
\quad(<47.26)\end{array}$ & $4.01 \pm 0.14^{\mathrm{b}}$ & $3.59 \pm 0.01^{c}$ & $3.28 \pm 0.01^{\mathrm{d}}$ & 7.6 & 5.5 & 3.5 & 2.5 & 1.3 \\
\hline Phenylalanine & $3.52 \pm 0.01^{\mathrm{b}}$ & $\begin{array}{c}3.96 \pm 0.02^{\mathrm{a}} \\
\quad(>11.11)\end{array}$ & $3.34 \pm 0.01^{c}$ & $3.34 \pm 0.02^{\mathrm{c}}$ & $3.25 \pm 0.03^{c}$ & 5.1 & - & - & - & 2.8 \\
\hline Histidine & $1.84 \pm 0.10^{\mathrm{b}}$ & $\begin{array}{l}2.22 \pm 0.01^{\mathrm{a}} \\
\quad(>20.65)\end{array}$ & $1.71 \pm 0.02^{\mathrm{c}}$ & $1.58 \pm 0.12^{\mathrm{d}}$ & $1.46 \pm 0.01^{\mathrm{d}}$ & 2.4 & 2.6 & 1.9 & 1.9 & 1.6 \\
\hline Tyrosine & $2.65 \pm 0.03^{b}$ & $\begin{array}{l}2.98 \pm 0.01^{\mathrm{a}} \\
\quad(>13.70)\end{array}$ & $2.31 \pm 0.03^{c}$ & $2.15 \pm 0.02^{\mathrm{d}}$ & $1.96 \pm 0.12^{\mathrm{e}}$ & 4.0 & - & - & - & - \\
\hline Cystine & $1.73 \pm 0.03^{b}$ & $\begin{array}{l}2.21 \pm 0.12^{\mathrm{a}} \\
\quad(>27.75)\end{array}$ & $1.66 \pm 0.01^{c}$ & $1.38 \pm 0.01^{\mathrm{d}}$ & $1.10 \pm 0.01^{\mathrm{e}}$ & 1.8 & - & - & - & - \\
\hline Arginine & $4.68 \pm 0.03$ & $\begin{array}{c}4.85 \pm 0.04 \\
\quad(>3.63)\end{array}$ & $4.68 \pm 0.01$ & $4.59 \pm 0.02$ & $4.42 \pm 0.03$ & 5.6 & - & - & - & 2.0 \\
\hline $\begin{array}{l}\text { Total essential } \\
\text { amino acids }\end{array}$ & 36.71 & $41.34(>12.61)$ & $34.99(<4.69)$ & $\begin{array}{c}32.84 \\
(<10.54)\end{array}$ & $30.89(<15.85)$ & 55.0 & & & & \\
\hline \multicolumn{11}{|c|}{ Non-essential amino acids } \\
\hline Alanine & $4.80 \pm 0.02$ & $\begin{array}{l}5.18 \pm 0.32 \\
\quad(>7.92)\end{array}$ & $4.47 \pm 0.10$ & $4.10 \pm 0.12$ & $3.89 \pm 0.01$ & 6.8 & & & & \\
\hline Serine & $4.20 \pm 0.01$ & $\begin{array}{c}3.06 \pm 0.05 \\
(<27.14)\end{array}$ & $4.08 \pm 0.13$ & $3.93 \pm 0.03$ & $3.46 \pm 0.10$ & 7.5 & & & & \\
\hline Proline & $4.29 \pm 0.14$ & $\begin{array}{c}3.71 \pm 0.32 \\
(<15.63)\end{array}$ & $3.94 \pm 0.10$ & $3.48 \pm 0.03$ & $3.25 \pm 0.02$ & 3.6 & & & & \\
\hline Aspartic acid & $22.31 \pm 0.51$ & $\begin{array}{l}23.26 \pm 0.74 \\
\quad(>4.26)\end{array}$ & $21.21 \pm 0.09$ & $20.26 \pm 0.08$ & $20.01 \pm 0.22$ & 7.6 & & & & \\
\hline Glutamic acid & $14.85 \pm 0.05$ & $\begin{array}{c}15.21 \pm 1.01 \\
\quad(>2.42)\end{array}$ & $14.28 \pm 0.15$ & $12.22 \pm 0.11$ & $11.29 \pm 0.71$ & 13.5 & & & & \\
\hline Glycine & $3.63 \pm 0.01$ & $\begin{array}{c}4.19 \pm 0.12 \\
(>15.43)\end{array}$ & $3.40 \pm 0.01$ & $3.38 \pm 0.02$ & $3.09 \pm 0.01$ & 3.6 & & & & \\
\hline
\end{tabular}




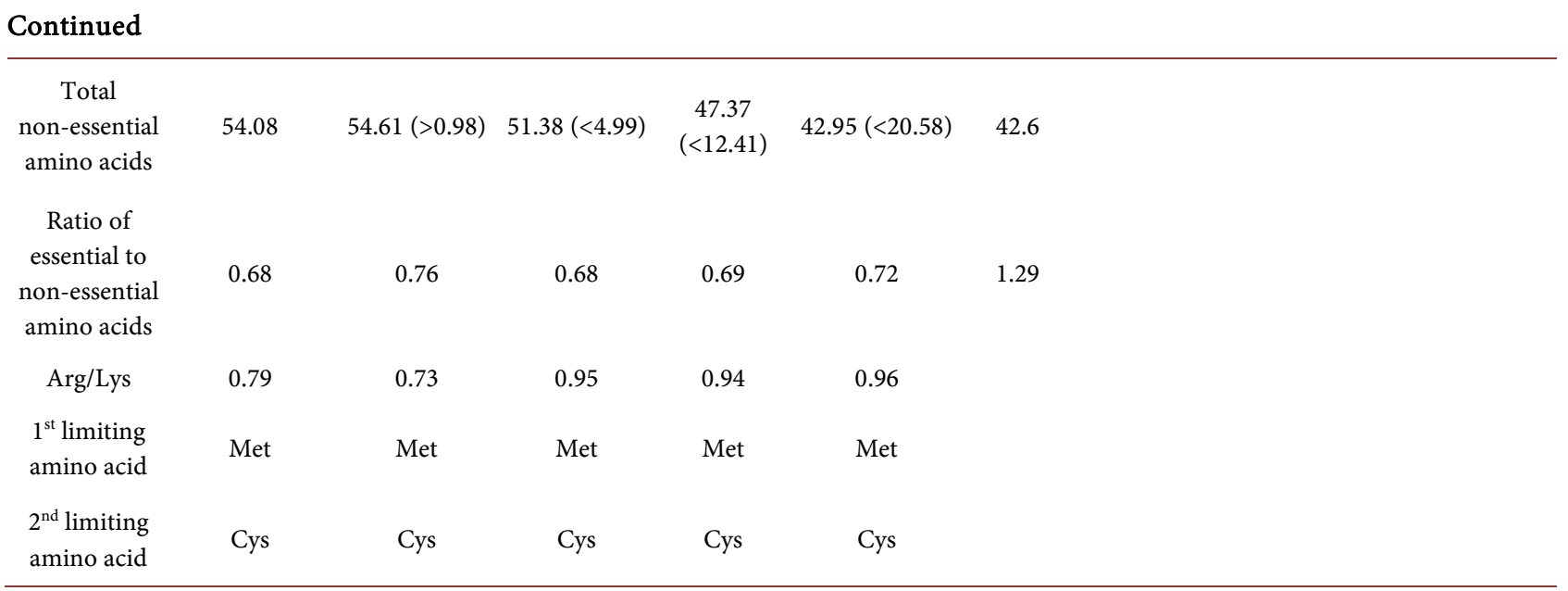

Values are mean \pm SEM $(n=3)$. Values in parenthesis show percentage increase or decrease in the amino acid composition due to processing; adopted from Iyenagbe et al. [53]. ${ }^{\mathrm{b}}$ Amino acid requirement $/ \mathrm{kg}$ divided by safe level of reference protein $/ \mathrm{kg} .{ }^{\mathrm{c}}$ Values adopted from Emmy Hainida et al. [47]. ${ }^{\mathrm{d}}$ Amino acid composition of human milk. ${ }^{\mathrm{e}}$ Individual aged 2 - 5 years. ${ }^{\mathrm{f}}$ Individual aged 10 - 12 years.

oil-rich protein seeds [16] [47] [50] [52]. However, increase due to dehulling is an indication that the kernel of sorrel seed contains the largest deposit of protein and amino acids in the seed, thus indicating the usefulness of dehulling as the best method for obtaining sorrel seed flour with enhanced protein quality. Thus, dehulled sorrel seed flour may serve as a better and more adequate protein supplement for human nutrition. Also, the highest lysine content of the dehulled seed flour which was higher than the FAO/WHO [53] human requirement may make this flour useful as a supplement food mixture for poor lysine food sources such as cereals used as weaning foods and a major staple in developing countries. Hence, it may contribute significantly to lysine content of complementary foods when combined with cereals (which are poor in lysine) and thus be useful for combating PEM in young children since values in this flour are higher than FAO/WHO [53] requirements for infants, pre-school and school age children.

Apart from the control sample which had $36.71 \%$ total essential amino acids, the dehulled seed flour (DDSF) was the only sample among the processed seed flours that met and exceeded (41.34\%) the 36\% recommended for an ideal protein [54]. Overall, roasting had the worst effect on the amino acids. The Arg/Lys ratios reported in this study (from 0.73 - 0.96) are lower than that of soybean (1.40) but higher than that for casein (0.44) [50]. Malomo et al. [55] reported that high ratio of Arg/Lys in the diet produces beneficial hypocholesterolemic effects that may improve cardiovascular health and help in regulation of hypertension. Hence, results obtained in the present study show potential of sorrel seed flours in impacting positive effects on the cardiovascular system.

Fatty acid composition of sorrel seed presented in Table 3 showed that sorrel seed is abundant in palmitic, linoleic, oleic and stearic acids as have been previously reported [15] [16], hence a rich source of these fatty acids. In most cases, processing had no significant $(\mathrm{p}<0.05)$ effect on the fatty acids. Oleic and linoleic acids observed to be most abundant unsaturated fatty acids have also been 
Table 3. Fatty acid composition and total carotenoid content of sorrel seed flours.

\begin{tabular}{|c|c|c|c|c|c|c|}
\hline FattyAcids (\%) & RDSF (Control) & DDSF & BDSF & ROSF & GDSF & $\begin{array}{c}\text { Codex } \\
\text { Alimentarius } \\
\text { Commission } \\
(2009)\end{array}$ \\
\hline Myristic acid (C14:0) & $2.23 \pm 0.11^{\mathrm{a}}$ & $2.26 \pm 0.11^{\mathrm{a}}$ & $2.21 \pm 0.11^{\mathrm{a}}$ & $2.51 \pm 0.11^{\mathrm{a}}$ & $2.27 \pm 0.11^{\mathrm{a}}$ & - \\
\hline Palmitic acid (C16:0) & $18.29 \pm 0.06^{\mathrm{b}}$ & $18.36 \pm 0.06^{\mathrm{b}}$ & $18.40 \pm 0.0^{\mathrm{b}}$ & $18.66 \pm 1.0^{\mathrm{ab}}$ & $18.22 \pm 0.1^{\mathrm{b}}$ & $8.0-13.5$ \\
\hline $\begin{array}{l}\text { Stearic acid } \\
(\mathrm{C} 18: 0)\end{array}$ & $6.29 \pm 0.72^{b}$ & $6.22 \pm 0.72^{\mathrm{b}}$ & $6.35 \pm 0.71^{\mathrm{ab}}$ & $6.27 \pm 0.71^{b}$ & $6.20 \pm 0.71^{b}$ & $2.0-5.4$ \\
\hline $\begin{array}{l}\text { Oleic acid } \\
(\mathrm{C} 18: 1)\end{array}$ & $22.28 \pm 0.09^{\mathrm{b}}$ & $22.02 \pm 1.00^{\mathrm{bc}}$ & $23.26 \pm 1.0^{\mathrm{ab}}$ & $23.17 \pm 1.0^{\mathrm{ab}}$ & $22.35 \pm 0.0^{\mathrm{b}}$ & $17.0-30.0$ \\
\hline Linoleic acid (C18:2) & $50.09 \pm 0.82^{\mathrm{b}}$ & $50.14 \pm 1.00^{\mathrm{ab}}$ & $50.17 \pm 1.0^{\mathrm{ab}}$ & $50.24 \pm 1.0^{\mathrm{a}}$ & $49.86 \pm 0.8^{c}$ & $48.0-59.0$ \\
\hline $\begin{array}{l}\text { Linolenic acid } \\
\text { (C18:3) }\end{array}$ & $1.51 \pm 0.16^{\mathrm{a}}$ & $1.59 \pm 1.00^{\mathrm{a}}$ & $1.55 \pm 0.15^{\mathrm{a}}$ & $1.50 \pm 0.16^{\mathrm{a}}$ & $1.53 \pm 0.16^{\mathrm{a}}$ & $4.5-11.0$ \\
\hline US: S & $3: 1$ & $3: 1$ & $3: 1$ & $3: 1$ & $3: 1$ & \\
\hline FFA & $0.72 \pm 0.01^{\mathrm{b}}$ & $0.84 \pm 0.02^{\mathrm{a}}$ & $0.56 \pm 0.01^{\mathrm{d}}$ & $0.42 \pm 0.01^{\mathrm{e}}$ & $0.61 \pm 0.02^{\mathrm{c}}$ & \\
\hline $\begin{array}{l}\text { Total Caroteno-id } \\
(\mathrm{mg} / 100 \mathrm{~g})\end{array}$ & $0.04 \pm 0.01^{\mathrm{a}}$ & $0.02 \pm 0.01^{\mathrm{abc}}$ & $0.03 \pm 0.01^{\mathrm{ab}}$ & $0.01 \pm 0.01^{\mathrm{c}}$ & $0.03 \pm 0.01^{\mathrm{ab}}$ & \\
\hline
\end{tabular}

Means \pm standard deviation for at least 3 determinations. Means with different superscripts on the same row are significantly different at $\mathrm{P}<0.05$. Legends: RDSF (Control), Raw Dried Sorrel Seed Flour; DDSF, Dehulled Dried Sorrel Seed Flour; BDSF, Boiled Dried Sorrel Seed Flour; ROSF, Roasted Sorrel Seed Flour; GDSF, Germinated Dried Sorrel Seed Flour; US: S, Ratio of Unsaturated to Saturated Fatty Acid; FFA, Free Fatty Acid.

similarly reported and have been linked to its high level of antioxidants, particularly tocopherols [56]. This accounts for the high ratio of saturated to unsaturated fatty acids of 1:3 observed for all the samples. This is in agreement with the range of 1:2-1:3 reported by El-Adawy and Khalil [15]. Since intake of adequate amounts of unsaturated fatty acids has been linked to physiological benefits on blood pressure, heart rate, endothelial function, cardiac diastolic function and reduced risk of fatal coronary heart disease [14], sorrel seed may be termed a functional food which may impart these physiological benefits and contribute significantly to maintaining consumers' health. All processing methods except dehulling reduced free fatty acid (FFA) from 0.72 to a range of $0.42-0.61$. Low FFA (0.42 - 0.84) reported in this present study is an indication that the oil is less prone to enzymatic hydrolysis since free fatty acid is an important index for oil quality. Thus, foods manufactured using sorrel seed and/or its oil will have a long shelf life and be free from off-flavor development during storage. Although insignificant (except in ROSF), total carotenoid content reduced in all cases and this may be due to its sensitivity to oxidation and high temperature during heat processing since heat treatment destroys heat-sensitive nutrients including vita$\operatorname{mins}[14]$.

\subsection{Anti-0xidative Potentials and Free Radical Scavenging Activity of Raw and Processed Sorrel Seed Flour}

Total phenolic content of sorrel flours ranged between 7.36 and $10.24 \mathrm{mg}$ GAE/g; processing significantly $(p<0.05)$ increased the phenolic content. De- 
hulling caused the highest increase from $7.36 \mathrm{mg} \mathrm{GAE} / \mathrm{g}$ to $10.24 \mathrm{mg} \mathrm{GAE} / \mathrm{g}$ and germination the lowest from $7.36 \mathrm{mg} \mathrm{GAE} / \mathrm{g}$ to $7.70 \mathrm{mg} \mathrm{GAE} / \mathrm{g}$ (Table 4). Oxidative stress ensues when there is an imbalance between the antioxidant system of the body and the formation of reactive oxygen species and phenolics act as antioxidants and have the ability to scavenge free radicals, which would otherwise build up in the body and cause harm [57]. Hence, increase in the phenolic content of sorrel seed due to processing and inclusion of these flours, especially DDSF into diets may provide protective roles against oxidative stress that can lead to the initiation phase of degenerative and cardiovascular diseases in human [58]. On the other hand, flavonoid content was significantly reduced by processing. Values ranging between $0.16 \mathrm{mg}$ rutin Eqv/mL and $0.96 \mathrm{mg}$ rutin Eqv/mL further shows that sample DDSF had the highest content as compared to other samples, hence the least reduction $(0.57 \mathrm{mg}$ rutin $\mathrm{Eqv} / \mathrm{mL})$ while no significant difference existed among samples BDSF (0.27 mg rutin Eqv/mL), ROSF ( $0.16 \mathrm{mg}$ rutin Eqv/mL) and GDSF (0.33 mg rutin Eqv/mL).

DPPH (2,2-diphenyl-1-picrylhydrazyl) is one of the assays used to determine free radical-scavenging activities. DPPH possesses a proton-free radical with a characteristic absorption which decreases significantly on exposure to proton radical scavengers. During the assay, a change from the characteristic purple to yellow indicates that the radicals in the reaction medium are scavenged resulting in decreased absorbance and the degree of decolourization is an indication of the scavenging ability of the samples [14] [59]. The DPPH radical-scavenging activity of the flours ranged between $56.42 \%$ and $88.83 \%$ as shown in Table 4 . These high values are an indication of the high radical-scavenging ability of sorrel seed. Processing significantly increased the DPPH of sorrel seed; RDSF (control sample) had the lowest value of $56.42 \%$, and sample DDSF (dehulled sorrel seed flour) had the highest activity (88.83\%). Thus, indicating that dehulling had the highest positive effect on the radical-scavenging ability of sorrel seed. DPPH of BDSF $(67.43 \%)$ and ROSF $(66.74 \%)$ were not significantly $(\mathrm{p}<0.05)$ different, whereas GDSF had the second highest value (80.74\%) (Table 4). Ferric reducing

Table 4. Antioxidant properties of sorrel seed flours.

\begin{tabular}{ccccc}
\hline Samples & $\begin{array}{c}\text { Total Phenolic } \\
\text { content } \\
(\mathrm{mg} / \mathrm{g})\end{array}$ & $\begin{array}{c}\text { Total Flavonoid } \\
(\mathrm{mg} \text { rutin } \\
\text { Eqv/mL) }\end{array}$ & DPPH (\%) & $\begin{array}{c}\text { FRAP } \\
(\mu \mathrm{g} \mathrm{Vit} \mathrm{C} \\
\text { E/mL) }\end{array}$ \\
\hline RDSF (Control) & $7.36 \pm 0.15^{\mathrm{d}}$ & $0.96 \pm 1.00^{\mathrm{a}}$ & $56.42 \pm 0.05^{\mathrm{e}}$ & $2.69 \pm 1.00^{\mathrm{a}}$ \\
DDSF & $10.24 \pm 0.15^{\mathrm{a}}$ & $0.57 \pm 1.00^{\mathrm{b}}$ & $88.83 \pm 1.00^{\mathrm{a}}$ & $2.37 \pm 1.00^{\mathrm{b}}$ \\
BDSF & $7.86 \pm 0.15^{\mathrm{c}}$ & $0.27 \pm 0.19^{\mathrm{c}}$ & $67.43 \pm 0.05^{\mathrm{c}}$ & $1.68 \pm 0.63^{\mathrm{d}}$ \\
ROSF & $9.21 \pm 0.15^{\mathrm{b}}$ & $0.16 \pm 1.00^{\mathrm{cd}}$ & $66.74 \pm 1.00^{\mathrm{cd}}$ & $2.15 \pm 1.00^{\mathrm{c}}$ \\
GDSF & $7.70 \pm 0.15^{\mathrm{c}}$ & $0.33 \pm 0.19^{\mathrm{c}}$ & $80.74 \pm 1.00^{\mathrm{b}}$ & $1.66 \pm 0.63^{\mathrm{d}}$ \\
\hline
\end{tabular}

Means \pm standard deviation for at least 3 determinations. Means with different superscripts on the same column are significantly different at $\mathrm{p}<0.05$. Legends: RDSF (Control), Raw Dried Sorrel Seed Flour; DDSF, Dehulled Dried Sorrel Seed Flour; BDSF, Boiled Dried Sorrel Seed Flour; ROSF, Roasted Sorrel Seed Flour; GDSF, Germinated Dried Sorrel Seed Flour. 
antioxidant power (FRAP) assay measures antioxidant power by the reduction of ferric iron $\left(\mathrm{Fe}^{3+}\right)$ to ferrous iron $\left(\mathrm{Fe}^{2+}\right)$. FRAP values ranged from $1.66-2.69 \mathrm{mg}$ Vitamin C Eqv/mL (Table 4). The control sample (RDSF) had the strongest reducing ability but was decreased by processing. Boiling (BDSF) and germination (GDSF) had the strongest negative effect on FRAP, while dehulling had the least negative effect with the highest value of $2.37 \mathrm{mg}$ Vitamin C Eqv/mL. This may indicate that dehulling will ensure the production of sorrel seed flour with higher antioxidative and scavenging activity than other processing methods.

\subsection{Functional Properties of Raw and Processed Sorrel Seed Flour}

Functional properties are non-nutritional, intrinsic characteristics of a food or food additive which affect the behaviour of proteins in food systems during processing, manufacturing, storage, preparation and consumption and are usually affected by processing treatments and the environment. These properties are important in determining the level of utilization of any flour in ingredient formulation and food product development and reflect the composition and conformation of proteins, and their interactions with other food components [23] [60]. During heat treatment, denaturation of protein occurs thereby influencing its functional properties and bringing about significant modification of physicochemical characteristics including dissociation into constituent subunits, unfolding and surface exposure of hydrophobic side groups [14]. This may explain changes observed in this present study.

\subsection{Water and Oil Absorption Capacities and Swelling Power}

Results in Table 5 showed that all processing methods significantly $(\mathrm{p}<0.05)$ increased water absorption of sorrel seed flour from $115 \%$ to a range of $165 \%$ $266 \%$; with highest increase in roasted seed flour (ROSF) and the lowest in DDSF. Iyenagbe et al. [50] reported similar higher increase of WAC in toasted

Table 5. Functional properties of sorrel seed flours.

\begin{tabular}{ccccccc}
\hline Samples & $\begin{array}{c}\text { WAC } \\
(\%)\end{array}$ & OAC (\%) & $\begin{array}{c}\text { Swelling } \\
\text { power (\%) }\end{array}$ & $\begin{array}{c}\text { Foaming } \\
\text { Capacity (\%) }\end{array}$ & $\begin{array}{c}\text { Foaming } \\
\text { Stability (\%) }\end{array}$ & $\begin{array}{c}\text { Emulsifying } \\
\text { Capacity (\%) }\end{array}$ \\
\hline $\begin{array}{c}\text { RDSF } \\
\text { (Control) }\end{array}$ & $115 \pm 1.00^{\mathrm{d}}$ & $156 \pm 1.00^{\mathrm{d}}$ & $74.0 \pm 1.00^{\mathrm{b}}$ & $16.66 \pm 1.00^{\mathrm{a}}$ & $50.00 \pm 1.00^{\mathrm{a}}$ & $66.67 \pm 1.00^{\mathrm{a}}$ \\
DDSF & $165 \pm 1.00^{\mathrm{c}}$ & $184 \pm 1.00^{\mathrm{b}}$ & $93.3 \pm 1.00^{\mathrm{a}}$ & $8.33 \pm 1.00^{\mathrm{b}}$ & $20.02 \pm 0.57^{\mathrm{d}}$ & $53.27 \pm 0.91^{\mathrm{b}}$ \\
BDSF & $264 \pm 1.00^{\mathrm{a}}$ & $166 \pm 0.13^{\mathrm{c}}$ & $49.1 \pm 1.00^{\mathrm{d}}$ & $4.84 \pm 1.00^{\mathrm{c}}$ & $33.24 \pm 1.00^{\mathrm{b}}$ & $33.77 \pm 1.00^{\mathrm{d}}$ \\
ROSF & $266 \pm 0.66^{\mathrm{a}}$ & $217 \pm 1.00^{\mathrm{a}}$ & $66.0 \pm 1.00^{\mathrm{c}}$ & $8.35 \pm 1.00^{\mathrm{b}}$ & $20.75 \pm 0.55^{\mathrm{c}}$ & $53.31 \pm 0.91^{\mathrm{b}}$ \\
GDSF & $206 \pm 1.00^{\mathrm{b}}$ & $173 \pm 0.13^{\mathrm{c}}$ & $19.5 \pm 1.00^{\mathrm{e}}$ & $3.35 \pm 1.00^{\mathrm{d}}$ & $20.18 \pm 0.57^{\mathrm{cd}}$ & $50.15 \pm 1.00^{\mathrm{c}}$ \\
\hline
\end{tabular}

Means \pm standard deviation for at least 3 determinations. Means with different superscripts on the same column are significantly different at $\mathrm{p} \leq 0.05$. Legends: RDSF (Control), Raw Dried Sorrel Seed Flour; DDSF, Dehulled Dried Sorrel Seed Flour; BDSF, Boiled Dried Sorrel Seed Flour; ROSF, Roasted Sorrel Seed Flour; GDSF, Germinated Dried Sorrel Seed Flour; WAC, Water Absorption Capacity; OAC, Oil Absorption Capacity. 
conophor seed flour. This increase may be due to protein denaturation which occurs during heat processing, resulting in increased WAC [50]. Also, increased protein content reported earlier in this study (Subsection 3.1) may account for increased WAC since proteins have the ability to absorb and retain water [61]. Values reported in this study (115\% - 266\%) are consistent with those previously reported for most defatted oilseed flours (100\% - 260\%), lupin seed (120\%), soy (130\%) and pigeon pea (138\%) flours [62]. Hence, both raw and processed sorrel seed flours may serve as functional ingredients in liquid and semi liquid foods like soups, gravies and baked products where water absorption/thickening is a critical factor; and may serve as good replacement for some legumes and oil seeds currently being used as thickeners since they will be relatively cheaper. Similarly, oil absorption increased (from $156 \%$ to $166 \%$ - 217\%) due to processing and again roasting caused the highest increase. Values reported in this study $(156 \%-217 \%)$ compare favourably with those for some oil seed flours $(140 \%$, $142 \%, 193 \%$ and $142 \%$ for chickpea, yam bean, soy and fluted pumpkin seed flours respectively) [62] [63] [64], but are higher than those reported for pigeon pea (89.7\%), jack bean (105.6\%) and gourd seed (96\%) flours [62] [65]. This further suggests their possible applicability in baked foods because good oil absorption capacity of flour samples is an indication of their usefulness in food preparations that involve oil mixing like in bakery products, where oil is an important ingredient [65]. Their use as composite in baked foods will not only improve protein quality of these foods whose major ingredient is wheat flour, but will also reduce amount of wheat in the product and the associated problems of gluten intolerance. The water/fat binding capacity of proteins which is an index of its ability to absorb and retain oil, influences flavour retention, texture and mouth feel of food products like ground meat formulations, doughnuts, pancakes, baked goods and soups [63]. Hence, sorrel seed flours can be used as flavour retainer and to improve the mouth feels of food.

On the other hand, significant reduction occurred in swelling power due to boiling (49.1\%), roasting (66.0\%) and germination (19.5); while only dehulling increased it (Table 5). The highest reduction caused by germination which may be due to activation of amylolytic enzymes during germination which degrade starch for use as energy source since swelling power of flours is associated with granule structure and chemical composition, particularly amylose and lipid content [66]. Also, heat processing has been reported to reduce swelling power of starch. Increase in swelling power due to dehulling implies that the flour may find wide application in food systems where retention of water is desirable especially in baked foods.

\subsection{Foaming and Emulsification Capacities}

Foaming capacity and stability were significantly reduced due to processing. Low foaming capacity and stability of both raw and processed sorrel seed flours (ranging from $3.35 \%-8.35 \%$ and $20.02 \%-33.24 \%$ respectively) indicate that the 
flours may find little or no application in foods such as ice-cream and alcoholic beverages where foaming is desirable, hence may not be useful as aerating agents in foods such as ice cream. This is because foams are very vital in foods like whipped toppings and beverages where the proteins unfold forming a layer that keeps air bubbles in suspension and prevents them from collapsing [50]. However, the low FS of the flours may indicate that very slow film formation at the air-water interfaces coupled with poor film visco-elasticity [55].

Similarly, emulsion capacity was significantly reduced by all processing methods from $66.67 \%$ in sample RDSF to $33.77 \%, 50.15 \%, 53.27 \%$ and $53.31 \%$ in samples BDSF, GDSF, DDSF and ROSF, respectively. While boiling caused the highest reduction, dehulling and roasting [which were not significantly $(\mathrm{p}<$ $0.05)$ different] resulted in the lowest decrease. Similar reduction has been reported in blanched fluted pumpkin seed flour and has been attributed to heat effect [64]. Values reported in this present study are higher than those previously reported for soya bean $(15.0 \%)$, breadnut (18\%), wheat (7\% - 11\%), calabash seed (23.2\%) and pigeon pea (49.1\%) flours [62] [65] [67] but are lower than $75.1 \%$ for sunflower flour [68]. Despite the reductions, sorrel seed flours can still find use as emulsifiers since relatively high values (ranging from $33.77 \%$ $66.67 \%$ ) were obtained. Emulsion capacity indicates the maximum amount of oil that can be emulsified by protein dispersion, hence, based on McWatters and Cherry's [68] model for describing thickness or emulsion consistency of flours; samples DDSF, ROSF and GDSF would have a thick mayonnaise-like emulsion (50 - $59 \mathrm{ml} / \mathrm{g}$ ), while the control flour (RDSF) with a higher value (66.67\%) would have a very thick mayonnaise-like $(>60 \mathrm{ml} / \mathrm{g}$ ) emulsion. However, sample BDSF having the lowest value (33.77\%) would have a very thick salad dressing-like emulsion (30 - $39 \mathrm{ml} / \mathrm{g}$ ). Hence, the flours can find use as emulsifying agents and meat additive in sausage production, salad dressing preparation, pie fillings, ice creams and mayonnaise.

\subsection{Protein Solubility}

There was an inconsistent reduction in the protein solubility of sorrel seed flour; at $\mathrm{pH} 3$, solubility increased from 4.78 in the control (RDSF) to 7.14 in BDSF; and at $\mathrm{pH} 6$ from 6.1 in RDSF to 6.22 and 6.82 in DDSF and BDSF respectively (Figure 1). Maximum protein solubility of 10.01 and 9.63 were obtained at $\mathrm{pH} 9$ for RDSF and GDSF, while minimum protein solubility of 2.64 was obtained at pH 8 in DDSF. Dehulled and roasted seed flours had maximum values of 6.22 and 5.43 at $\mathrm{pH}$ 6, while BDSF had maximum solubility of 7.14 at $\mathrm{pH} 3$. Minimum protein solubility for BDSF (4.27) and GDSF (3.52) was reached at $\mathrm{pH} 2$, while the control had minimum value of 4.78 at $\mathrm{pH} 3$. Decreased protein solubility which has been linked to reduced in vitro protein digestibility in this study (Subsection 3.1) may be attributed to denaturation of proteins and increase in amounts of insoluble protein aggregates; carbohydrates and polyphenols during heating [34]. Thus, the control (RDSF) and sprouted (GDSF) seed flours with 


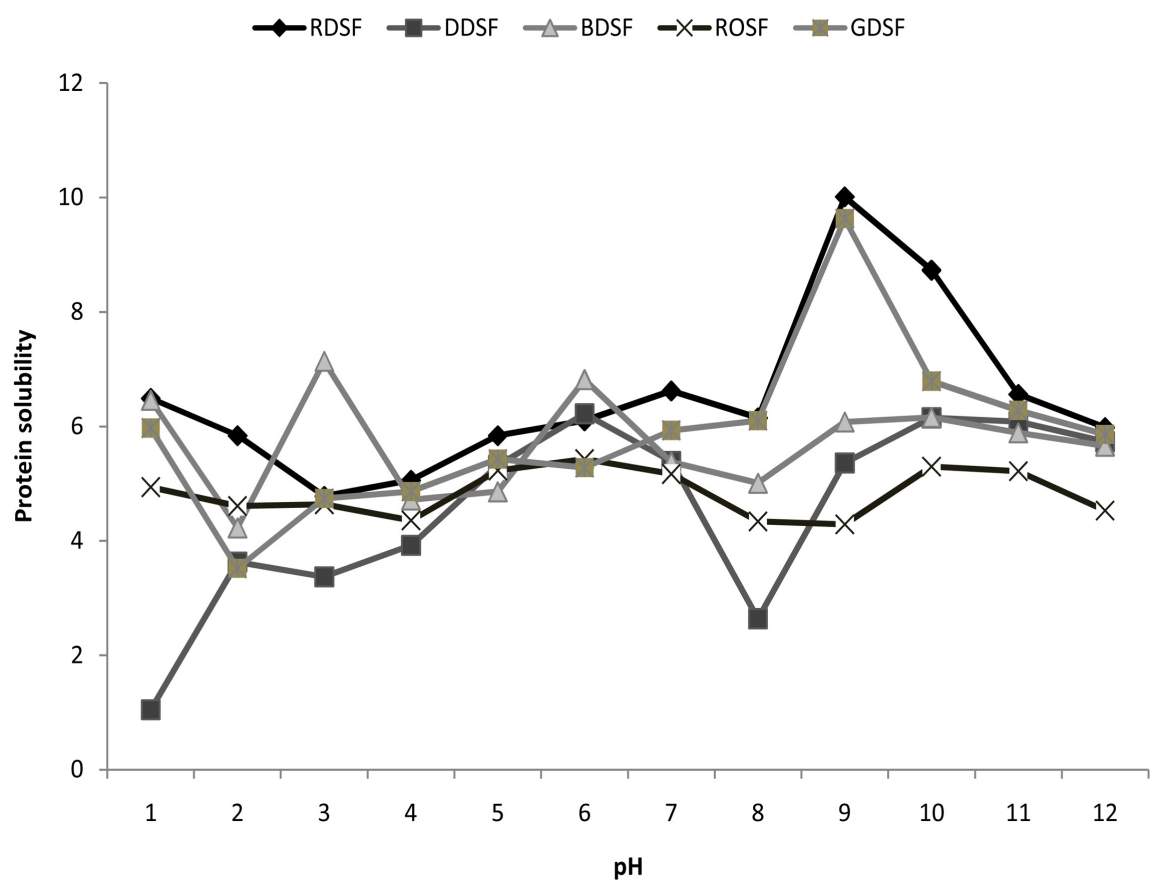

Figure 1. Effect of processing on protein solubility of sorrel seed flour. Legends: RDSF (Control), Raw Dried Sorrel Seed Flour; DDSF, Dehulled Dried Sorrel Seed Flour; BDSF, Boiled Dried Sorrel Seed Flour; ROSF, Roasted Sorrel Seed Flour; GDSF, Germinated Dried Sorrel Seed Flour.

high protein solubility at $\mathrm{pH} 9$ may be useful in vegetable milk production where emulsification is important [62].

\subsection{Effect of Processing on the Antinutrient Contents of Sorrel Seed Flour}

Figure 2 which presents the effects of different processing methods on the antinutrient content of sorrel seed showed that of the antinutrients determined, saponin was most abundant in sorrel seed, with values ranging from $6.89-30.26$ $\mathrm{mg} / \mathrm{g}$. It was followed by phytate $(3.93-9.12 \mathrm{mg} / \mathrm{g})$, tannin $(2.47-6.04 \mathrm{mg} / \mathrm{g})$ and oxalate $(1.30-3.23 \mathrm{mg} / \mathrm{g})$. Processing significantly $(\mathrm{p}<0.05)$ reduced saponin; roasting caused the highest reduction from $30.26 \mathrm{mg} / \mathrm{g}$ to $6.89 \mathrm{mg} / \mathrm{g}$. The trend in decreasing order was DDSF > GDSF > BDSF > ROSF. A similar trend was observed for oxalate and tannin contents, while for phytate the trend was slightly different DDSF > GDSF > ROSF > BDSF. These results indicate that heating had the most significant effect on the antinutrients as compared to germination and dehulling. Hence, irrespective of the processing method used, sorrel seed meant for human consumption has to be subjected to some form of heating to reduce the antinutrient content and enhance safety from toxigenic components.

\section{Conclusion}

Results of the present study have shown that dehulling has the potential of 


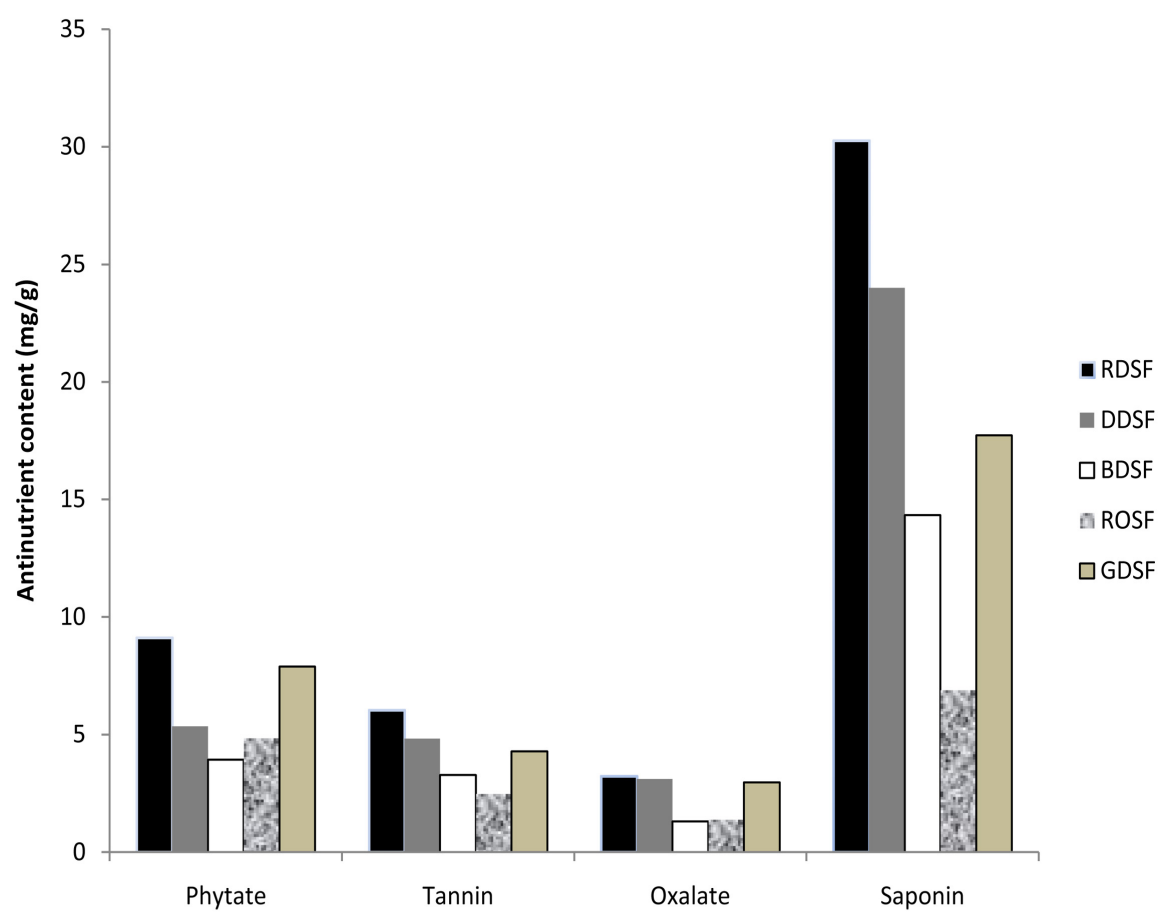

Figure 2. Antinutrient content of sorrel seed flours (mg/g) as affected by processing. Legends: RDSF (Control), Raw Dried Sorrel Seed Flour; DDSF, Dehulled Dried Sorrel Seed Flour; BDSF, Boiled Dried Sorrel Seed Flour; ROSF, Roasted Sorrel Seed Flour; GDSF, Germinated Dried Sorrel Seed Flour.

improving protein quality and food functionality of the under-utilized sorrel seed and make it an important source of nutritional amino acid for human nutrition and a functional ingredient in food product development. Dehulling enhanced the nutritional, antioxidative and functional properties of sorrel seed as compared to other methods that have been previously used. Hence, the dehulled seed flour may provide a higher source of nutritional protein supplement and a better source of essential amino acid. High in vitro digestibility values especially in the dehulled seed flour indicate that the protein of these flours is highly digestible and as such can serve as a nutritional source of amino acid. Also, the dehulled seed flour (DDSF) exhibited the highest antioxidative and radical-scavenging activities as compared to other processed seed flours thus indicating that greater amounts of the bioactive compounds of sorrel seed are present in the kernel than in the hulls/seed coat. Thus, removal of the hull aided in concentrating the antioxidants in the kernels. Good thickening and emulsifying properties of the flours indicate they can find use as functional food ingredients for food product development. However, the lowest amounts of ash and minerals in the dehulled seed flour may necessitate micronutrient fortification of this flour when being used as a protein-enhancer in cereal-based complementary foods. Further in vivo studies are required to ascertain true biological values and health benefits of dehulled sorrel seed flour. Further studies are also required to verify the food product applicability of the flour and to optimize the traditional dehul- 
ling process for mechanical dehulling so as to remove the drudgery associated with the manual dehulling process. This will encourage increased production, widespread acceptance and consumption of this flour.

\section{Acknowledgements}

The authors acknowledge Mrs. Omoniyi and Mr Festus Ibeh of the Department of Food Science and Technology, Federal University of Technology, Akure, Ondo State, Nigeria and Mr Akintunde Akinlabi and Dr. Ojobe of the University of Jos, Nigeria for their technical assistance.

\section{Conflicts of Interest}

The authors declare no conflict of interest (financial or non-financial).

\section{References}

[1] FAO (2005) The State of Food Insecurity in the World 2005. Rome. http://www.fao.org/3/a-a0200e.pdf

[2] Müller, O. and Krawinkel, M. (2005) Malnutrition and Health in Developing Countries. CMAJ, 173, 279-286. https://doi.org/10.1503/cmaj.050342

[3] Duncan, T. (2001) Commission on Macroeconomics and Health. Health, Nutrition and Economic Prosperity: A Microeconomic Perspective. CMH Working Papers No WG1:7. World Health Organization, Geneva.

[4] Cleaver, K., Okidegbe, N. and De Nys, E. (2006) Agriculture and Rural Development: Hunger and Malnutrition. World Bank Seminar Series: Global Issues Facing Humanity, 1-18.

[5] Young, V.R. and Pellet, P.L. (1990) Current Concepts Concerning Indispensable Amino Acids Needs in Adults and Their Implications for International Nutrition Planning. Food and Nutrition Bulletin, 12, 289-300. https://doi.org/10.1177/156482659001200414

[6] Volgarev, M.N. and Waggle, D.H. (1992) Introduction. In: Steinke, F.H., Waggle, D.H. and Volgarev, M.N., Eds., New Protein Foods in Human Health: Nutrition Prevention and Therapy, CRC Press Inc., Boca Raton and London, 1-8.

[7] Liener, I.E. (1980) Introduction. In: Liener, I.E., Ed., Toxic Constituents of Plant Food Stuffs, 2nd Edition, Academic Press, Inc., New York, 1-5.

[8] Bressani, R., Elias, L.G. and Braham, J.E. (1982) Reduction of Digestibility of Legume Protein of Tannins. Journal of Plant Foods, 4, 43-55. https://doi.org/10.1080/0142968X.1982.11904247

[9] Wolf, W.J. (1992) Protein Sources for Use in Food Products. In: Steinke, F.H., Waggle, D.H. and Volgarev, M.N., Eds., New Protein Foods In-Human Health: $\mathrm{Nu}$ trition, Prevention and Therapy, CRC Press Inc., Boca Raton and London, 33-46.

[10] Chavan, U., McKenzie, D. and Shahidi, F. (2001) Functional Properties of Protein Isolates from Beach Pea (Lathyrus maritimus L.). Food Chemistry, 74, 177-187. https://doi.org/10.1016/S0308-8146(01)00123-6

[11] Al-Wandawi, H., Al-Shaikhly, K. and Abdul-Rahman, M. (1984) Roselle Seed: A New Protein Source. Journal of Agricultural and Food Chemistry, 32, 510-512. https://doi.org/10.1021/jf00123a022

[12] Kwari, I.D., Diarra, S.S., Raji, A.O. and Adamu, S.B. (2011) Egg Production and Egg 
Quality Laying Hens Fed Raw or Processed Sorrel (Hibiscus sabdariffa) Seed Meal. Agriculture and Biology Journal of North America, 2, 616-621. https://doi.org/10.5251/abjna.2011.2.4.616.621

[13] Halimatul, S.M.N., Amin, I., Mohd.-Esa, N., Nawalyah, A.G. and SitiMuskinah, M. (2007) Protein Quality of Roselle (Hibiscus sabdariffa L.) Seeds. ASEAN Food Journal, 14, 131-140.

[14] Amin, I., Hainida, E.K.I. and Halimatul, S.M.N. (2008) Roselle (Hibiscus sabdariffa L.) Seeds-Nutritional Composition, Protein Quality and Health Benefits. Food, 2, $1-16$.

[15] El-Adawy, T.A. and Khalil, A.H. (1994) Characteristic of Roselle Seeds as a New Source of Protein and Lipid. Journal of Agricultural and Food Chemistry, 42, 1896-1900. https://doi.org/10.1021/jf00045a013

[16] Rao, P.U. (1996) Nutrient Composition and Biological Evaluation of Mesta (Hibiscus sabdariffa) Seeds. Plant Foods in Human Nutrition, 49, 27-34. https://doi.org/10.1007/BF01092519

[17] Abu-Tarboush, H.M., Ahmed, S.A.B. and Al Kahtani, H.A. (1997) Some Nutritional and Functional Properties of Karkade (Hibiscus sabdariffa) Seed Products. Cereal Chemistry, 74, 352-355. https://doi.org/10.1094/CCHEM.1997.74.3.352

[18] Yagoub, A.A. and Mohammed, M.A. (2008) Fururndu, a Meat Substitute from Fermented Roselle (Hibiscus sabdariffa L.) Seed: Investigation on Amino Acids Composition, Protein Fractions, Minerals Content and HCl-Extractability and Microbial Growth. Pakistan Journal of Nutrition, 7, 352-358. https://doi.org/10.3923/pjn.2008.352.358

[19] Schippers, R.R. (2000) African Indigenous Vegetable: An Overview of the Cultivated Species. Natural Resources Institute/ACP-EU. Technical Center for Agricultural and Rural Cooperation, Chatam, 1-124.

[20] Morton, J.F. (1987) Roselle. In: Fruits of Warm Climates, Florida Flair Books, Miami, 281-286.

[21] Cater, C.M., Cravens, W.W., Horan, F.E., Lewis, C.J., Mattil, K.F. and Williams, L.D. (1978) Oilseed Proteins. In: Milner, M., Scrimshaw, N.S. and Wang, D.I.C., Eds., Protein Resources and Technology. Status and Research Needs, 2AVI Publishing Company, West Port, 78-301.

[22] Oomah, B.D., Mazza, G. and Przybylski, R. (1996) Comparison of Flaxseed Meal Lipids Extracted with Different Solvents. Lebensmittel Wissenschaft und Technologie, 29, 654-658. https://doi.org/10.1006/fstl.1996.0100

[23] Tasneem, R., Ramsmani, S. and Subramaja, V. (1982) Functional Properties of Guar Seed Cyamopsis tetragonoloba Meal Detoxified by Different Methods. Journal of Food Science, 47, 1323-1328. https://doi.org/10.1111/j.1365-2621.1982.tb07678.x

[24] Tounkara, F., Amadou, I., Le, G.W. and Shi, Y.H. (2011) Effect of Boiling on the Physicochemical Properties of Roselle Seeds (Hibiscus sabdariffa L.) Cultivated in Mali. African Journal of Biotechnology, 10, 18160-18166.

[25] Duwa, H., Oyawoye, E.O. and Njidda, A.A. (2012) Effect of Processing Methods on the Utilization of Sorrel Seed Meal by Broilers. Pakistan Journal of Nutrition, 11, 38-46. https://doi.org/10.3923/pjn.2012.38.46

[26] AOAC (1990) Official Methods of Analysis. Association of Analytical Chemists, Washington DC.

[27] Isaac, R.C. and Johnson, W.C. (1975) Collaborative Study of Wet and Dry Techniques for the Elemental Analysis of Plant Tissue by Atomic Absorption Spectrophotometer. Journal of the Association of Analytical Chemistry, 58, 436. 
[28] Jones, J. and Case, V. (1990) Sampling, Handling and Analyzing Plant Tissue Samples. In: Westerman, R.L., Ed., Soil Testing and Plant Analysis, SSSA Book Series No. 3, 3rd Edition.

[29] Oh, K.S. (1994) Changes in Lipid Components of Pollack during Sun Drying. Korean Journal of Food Science and Technology, 18, 123-126.

[30] Akintayo, E.T. and Bayer, E. (2002) Characterization and Possible Uses of Plukenatia conophora and Adenopus breviflorus Seed and Seed Oil. Bioresource Technology, 85, 95-97. https://doi.org/10.1016/S0960-8524(02)00073-1

[31] Rodríguez-Amaya, D.B. and Kimura, M. (2004) Harvestplus Handbook for Carotenoid Analysis. International Food Policy Research Institute, Washington DC, 34-36.

[32] Hsu, H.W., Vavak, D.L., Satterlee, L.D. and Miller, G.A. (1977) A Multi-Enzyme Technique for Estimating Protein Digestibility. Journal of Food Science, 42, 12691273. https://doi.org/10.1111/j.1365-2621.1977.tb14476.x

[33] Sigh, U., Klierdeker, M.S. and Jambunathan, R. (1982) Studies on Desi and Kabu li Chickpeas (Cicer arieinum L.) Cultivars. The Level of Protein Inhibitors, Level of Oligosaccharides and In-Vitro Digestibility. Journal of Food Science, 47, 510-412. https://doi.org/10.1111/j.1365-2621.1982.tb10113.x

[34] Butrits, M. and Bucar, F. (2000) Antioxidant Activity of Nigeria Sativa Essential Oil. Phytotheraphy Research, 14, 323-328. https://doi.org/10.1002/1099-1573(200008)14:5<323::AID-PTR621>3.0.CO;2-Q

[35] Singleton, V.L., Orthofer, R. and Lamuela-Raventos, R.M. (1999) Analysis of Total Phenols and Other Oxidation Substrates and Antioxidants by Means of Folin Ciocalteu Reagent. Methods Enzymology, 299, 152-177. https://doi.org/10.1016/S0076-6879(99)99017-1

[36] Meda, A., Lamien, C.E., Romito, M., Millogo, J. and Nacoulma, O.G. (2005) Determination of the Total Phenolic, Flavonoid and Proline Contents in Burkina Fasan Honey, as Well as Their Radical Scavenging Activity. Food Chemistry, 91, 571-577. https://doi.org/10.1016/j.foodchem.2004.10.006

[37] Pulido, R., Bravo, L. and Saura-Calixto, F. (2002) Antioxidant Activity of Dietary Polyphenols as Determined by a Modified Ferric Reducing/Antioxidant Power Assay. Journal of Agricultural and Food Chemistry, 48, 3396-3402. https://doi.org/10.1021/jf9913458

[38] Rodriguez-Ambriz, S., Martinez-Ayala, A., Millan, F. and Davila-Ortiz, G. (2005) Composition and Functional Properties of Lupinus campestris Protein Isolates. Plant Foods for Human Nutrition, 60, 99-107. https://doi.org/10.1007/s11130-005-6835-Z

[39] Omowaye-Taiwo, O.A., Fagbemi, T.N., Ogunbusola, E.M. and Badejo, A.A. (2015) Effect of Germination and Fermentation on the Proximate Composition and Functional Properties of Full-Fat and Defatted Cucumeropsis mannii Seed Flours. Journal of Food Science and Technology, 52, 5257-5263. https://doi.org/10.1007/s13197-014-1569-2

[40] Ukpabi, U.J. and Ndimele, C. (1990) Evaluation of Quality of Gari Produced in Imo State. Nigerian Food Journal, 8, 106-109.

[41] Sze-Tao, K.W. and Sathe, S.K. (2000) Functional Properties and in Vitro Digestibility of Almond (Prunus dulcis L.) Protein Isolate. Food Chemistry, 69, 153-160. https://doi.org/10.1016/S0308-8146(99)00244-7

[42] Palić, D., Morey, L., Modika, K.Y., Kokić, B., Djuragić, O. and Spasevski, N. (2012) Precision of Laboratory Methods Based on Protein Solubility in Quality Control of Heat Treated Feedstuffs. Chemistry and Industry, 66, 53-57. 
https://doi.org/10.2298/HEMIND110623054P

[43] Wheeler, E.L. and Ferrel, R.E. (1971) A Method for Phytic Acid Determination in Wheat and Wheat Fraction. Journal of Cereal Chemistry, 48, 312-320.

[44] Makkar, H.P.S. (1994) Quantification of Tannins: A Laboratory Manual. International Centre for Agricultural Research in the Dry Areas (ARDA), Alleppo Syria.

[45] Day, R.A. and Underwood, A.L. (1986) Quantitative Analysis. 5th Edition, Prentice-Hall Publication, 701.

[46] AOAC (2005) Official Methods of Analysis. 18th Editon, Association of Analytical Chemist, Washington DC, 4.

[47] Emmy Hainida, K.I., Amin, I., Normah, H. and Mohd-Esa, N. (2008) Nutritional and Amino Acid Contents of Differently Treated Roselle (Hibiscus sabdariffa L.) Seeds. Food Chemistry, 111, 906-911. https://doi.org/10.1016/j.foodchem.2008.04.070

[48] FAO (2001) Improving Nutrition through Home Gardening-A Training Package for Preparing Field Workers in Africa, Food and Nutrition Division in collaboration with Plant Production and Protection Division, FAO, Rome, Italy. http://www.fao.org/home/en/

[49] Yu-Hui, T. (1991) Effect of the Hard-to-Cook Defect and Processing on Protein and Starch Digestibility of Cow-Peas. Cereal Chemistry, 68, 413-418.

[50] Iyenagbe, D.O., Malomo, S.A., Idowu, A.O., Badejo, A.A. and Fagbemi, T.N. (2017) Effects of Thermal Processing on the Nutritional and Functional Properties of Defatted Conophor Nut (Tetracarpidium conophorum) Flour and Protein Isolates. Food Science and Nutrition, 5, 1170-1178. https://doi.org/10.1002/fsn3.508

[51] Ogunbusola, E.M., Fagbemi, T.N. and Osundahunsi, O.F. (2013) In-Vitro Protein Digestibility, Amino Acid Profile, Functional Properties and Utilization of White Melon (Cucumeropsis mannii) Protein Isolates. Journal of Food Science and Technology, 4, 153-159.

[52] Fagbemi, T.N. (2009) Effect of Processing on Chemical Composition of Cashewnut (Anacardium occidentale). Journal of Food Science and Technology, 46, 36-40.

[53] FAO/WHO (1991) Protein Quality Evaluation. In: Report of Joint FAO/WHO EXpert Consultation, Food and Agriculture Organization of the United Nations, Rome, FAO Food and Nutrition Paper 51.

[54] FAO/WHO (2007) Protein Quality Evaluation. In: Report of the Joint FAO/WHO Expert Consultation, Food and Agriculture Organizations and the World Health Organization, Rome, Food and Nutrition No. 69.

[55] Malomo, S.A., He, R. and Aluko, R.E. (2014) Structural and Functional Properties of Hemp Seed Protein Products. Journal of Food Science, 79, C1512-C1521. https://doi.org/10.1111/1750-3841.12537

[56] Mohamed, R., Fernandez, J., Pineda, M. and Aguilar, M. (2007) Roselle (Hibiscus sabdariffa) Seed Oil Is a Rich Source of Gamma-Tocopherol. Journal of Food Science, 72, 207-211. https://doi.org/10.1111/j.1750-3841.2007.00285.x

[57] Fang, Y.Z., Yang, S. and Wu, G. (2002) Free Radicals, Antioxidants, and Nutrition. Nutrition, 18, 872-879. https://doi.org/10.1016/S0899-9007(02)00916-4

[58] Baenas, N., Garcia-Viguera, C. and Moreno, D.A. (2014) Elicitation: A Tool for Enriching the Bioactive Composition of Foods. Molecules, 19, 13541-13563. https://doi.org/10.3390/molecules190913541

[59] Yamaguchi, T., Takamura, H., Matoba, T. and Terao, J. (1998) HPLC Method for Evaluation of the Free Radical-Scavenging Activity of Foods by Using 1,1-diphenyl- 
2-picrylhydrazyl. Bioscience, Biotechnology, and Biochemistry, 62, 1201-1204. https://doi.org/10.1271/bbb.62.1201

[60] Altschul, A.M. and Wilcke, H.L. (1985) New Protein Foods: Food Science and Technology, a Series of Mongraphs.

[61] Prinyawiwutku, W., McWatters, K.H., Beuchat, L.R. and Phillips, R.D. (1994) Physical Properties of Cowpea Paste and Akara as Affected by Supplementation with Peanut Flour. Food Chemistry, 42, 1750-1756. https://doi.org/10.1021/jf00044a034

[62] Oshodi, A.A. and Ekperijin, N.M. (1989) Functional Properties of Pigeon Pea Flour (Cajanus cajan). Food Chemistry, 34, 187-191. https://doi.org/10.1016/0308-8146(89)90139-8

[63] Akinyede, A.I., Amoo, I.A. and Eleyinmi, A.F. (2005) Chemical and Functional Properties of Full Fat and Defatted Dioclea reflexa Seed Flours. Journal of Food, Agriculture and Environment, 3, 112-115. http://www.world-food.net

[64] Fagbemi, T.N., Oshodi, A.A. and Ipinmoroti, K.O. (2006) Effects of Processing on Functional Properties of Full Fat and Defatted Fluted Pumpkin (Telfaria accidentalis) Seed Flours. Journal of Food Technology, 4, 70-79.

[65] Olaofe, O., Adeyemi, F.O. and Adediran, G.O. (1994) Amino Acid, Chemical Composition and Functional Properties of Some Oil Seeds. Journal of Agricultural and Food Chemistry, 42, 879-881. https://doi.org/10.1021/jf00040a007

[66] Zheng, G.H. and Sosulski, F.W. (1997) Physicochemical Properties of Small Granule Starches. AACC Annual Meeting, San Diego.

[67] Lin, M.J.Y., Humbert, E.S. and Sosulski, F.W. (1974) Certain Functional Properties of Sunflower Meal Products. Journal of Food Science, 39, 368-370. https://doi.org/10.1111/j.1365-2621.1974.tb02896.x

[68] Mcwatters, K.H. and Cherry, J.P. (1981) Emulsification Vegetable Proteinsin "Protein Functionality in Foods". American Chemical Society, Washington DC, $217-$ 242. https://doi.org/10.1021/bk-1981-0147.ch011 